\title{
THE ANDEAN GENUS MYROSMODES (ORCHIDACEAE, CRANICHIDEAE) IN PERU
}

\section{Delsy Trujillo ${ }^{1,2,5}$, Paúl Gonzáles ${ }^{3}$, Huber Trinidad ${ }^{3}$ \& Asunción Cano Cano $^{3,4}$}

${ }^{1}$ Herbario MOL, Facultad de Ciencias Forestales, Universidad Nacional Agraria La Molina

${ }^{2}$ Herbario San Marcos (USM), Museo de Historia Natural, Universidad Nacional Mayor de San Marcos, Av. Arenales 1256, Jesús María, Lima 11, Perú

${ }^{3}$ Laboratorio de Florística, Departamento de Dicotiledóneas, Museo de Historia Natural, Universidad Nacional Mayor de San Marcos, Av. Arenales 1256, Lima 11, Perú

${ }^{4}$ Instituto de Investigación de Ciencias Biológicas Antonio Raimondi, Facultad de Ciencias Biológicas, Nacional Mayor de San Marcos, Av, Venezuela s/n cuadra 34, Lima 1, Perú

${ }^{5}$ Author for correspondence: delsytrujillo@lamolina.edu.pe

\begin{abstract}
A revision of Myrosmodes from Peru is presented. Seven species are recognized for the country. Each species is described and illustrated on the basis of a revision of type material, protologues and Peruvian specimens. Its distribution within the country is assessed. Myrosmodes nervosa is recorded for first time in Peru. New synonyms are proposed: M. cleefii is included under M. nubigena, M. inaequalis and M. pumilio under M. paludosa, M. weberbaueri under M. gymnandra, and M. cochlearis under M. rhynchocarpa. A key to identify the seven recognized species is also provided. A lectotype is designated for Aa chiogena.
\end{abstract}

Resumen: Se presenta una revisión de Myrosmodes del Perú. Se aceptan siete especies para el país. Se describe e ilustra cada especie con base en la revisión del material tipo, protólogos y material peruano. Se evalúa su distribución en el país. Myrosmodes nervosa se registra por primera vez para el Perú. Se proponen nuevos sinónimos: M. cleefii es incluido bajo la sinonimia de M. nubigena, M. inaequalis y M. pumilio bajo M. paludosa, M. weberbaueri bajo M. gymnandra y M. cochlearis bajo M. rhynchocarpa. También se proporciona una clave para identificar las especies reconocidas. Se designa un lectotipo para Aa chiogena.

KeY words: Myrosmodes, High Andean, orchids, lectotype

Reichenbach (1854) described Myrosmodes based on Myrosmodes nubigena Rchb.f. In subsequent works, the genus was considered as a synonym of Altensteinia Kunth (Reichenbach 1878, Schweinfurth 1958) or Aa Rchb.f. (Schlechter 1912, 1920a, 1920b, 1921, 1922). After one century of confusion, Garay (1978) reinstated Myrosmodes, transferring some species of Aa and Altensteinia to Myrosmodes and describing a new species. Since then, more species were transferred to Myrosmodes (Ortiz 1995, Vargas 1995, Trujillo \& Vargas 2011, Novoa et al. 2015). At the moment, without considering the heterotypic synonyms, 17 names are referable to Myrosmodes.

Myrosmodes is distinguished from Aa and Altensteinia based on morphological characters (Trujillo \& Vargas 2011). Notwithstanding, species determination could be problematic, particularly in herbaria. The difficulties are mainly because species have uniform vegetative features, exhibit quite similar tiny flowers except for some features able to be seen only under the stereomicroscope. Also, original descriptions of some species have limited diagnostic features and several type specimens were destroyed during the Second World War.

Molecular phylogenetic analysis conducted by Álvarez-Molina \& Cameron (2009) indicates that Myrosmodes and Aa belong to the Altensteinia clade (Cranichideae), together with the predominantly Andean genera: Altensteinia, Gomphichis Lindl., Porphyrostachys Rchb.f., and Stenoptera C.Presl. The study also indicates that Myrosmodes may be embedded within $A a$; however, as pointed out by the authors, a better sampled phylogenetic analysis is needed to clarify the generic limits.

The present contribution aims to provide additional information on morphology that helps species identification in Myrosmodes. Although here we emphasize on species occurring in Peru, we include comments on distribution in other Andean countries. 


\section{KEY TO THE RELATED GENERA}

1. Inflorescence terminal; rachis of the spike pubescent or densely pilose; flowers at least $1 \mathrm{~cm}$ in diameter; ovary and sepals pilose; column pubescent; clinandrium large and lobulate

Altensteinia

1a. Inflorescence lateral, rachis of the spike glabrous or sparsely pilose; flowers less than $1 \mathrm{~cm}$ in diameter; ovary and sepals glabrous or sparsely pilose; column glabrous; clinandrium small

2. Peduncle elongate, thin and completely enclosed by loose to tight-fitting, cylindrical sheaths; rachis of the spike and ovary sparsely pilose (or glabrous in some species); floral bracts longer than the flowers; dorsal sepal and petals free from column; lip calceolate with involute and lacerate margin

2a. Peduncle acrescent, thick and completely enclosed by imbricate infundibuliform sheaths; rachis of the spike and ovary glabrous; floral bracts same size or little shorter than the flower; dorsal sepal and petals adnate to back of column above base; lip cucullate with the margin irregularly erose or with moniliform hairs

Myrosmodes

Myrosmodes Rchb.f., Xenia Orchid. 1: 19. 1854.

TYPE SPECIES: Myrosmodes nubigena Rchb.f.

Plant small, 1.2-6.8 cm tall. Roots fleshy, fasciculate, fusiform (Fig. 1A). Leaves 3-7, fleshy, forming a basal rosette, petiolate, sheathing base, blades elliptic-lanceolate or ovate, acute or shortly acuminate (Fig. 1B), up to $2.0 \times 1.5 \mathrm{~cm}$, shorter than the scape. Inflorescence lateral and andromonoecious (producing both hermaphroditic and female-sterile flowers); peduncle thick, acrescent, completely enclosed by imbricate, infundibuliform, hyaline, sheaths, 2.0-8.0 $\mathrm{cm}$ long (but it elongates up to $17 \mathrm{~cm}$ long during fruit maturation); spike conic to cylindrical, densely many-flowered, with flowers of different size along its length (increasing in size towards the base) (Fig. 1C-D). Floral bracts elliptic-oblong to suborbicularovate, hyaline, brownish apex, same size or little shorter than the flower. Flowers small, non-resupinate, glabrous, white and green. Sepals oblong to ovate, obtuse to rounded at apex; dorsal sepal adnate to the column near the base; lateral sepals oblique, shortly connate at the base to up half their length. Petals linear, falcate, shortly adnate to the column near the base. Lip cucullate, with the margins irregularly erose or with moniliform hairs (Fig. 1E), with two calli at the base, finely papillose on the posterior surface above. Column erect, dilated above. Anther dorsal, erect, elliptic to ovate, enclosed in the clinandrium. Stigma elliptic, reniform or quadrate. Pollinia four, sessile on a prominent viscidium. Ovary glabrous, empty in the apical flowers of the inflorescence (functional male flowers).

Distribution: Found in the Andean region from
Venezuela (Dunsterville \& Garay 1966, Foldats 1969), Colombia (Ortiz 1995, Szlachetko et al. 2014), Ecuador (Garay 1978), Peru (Schweinfurth 1958), Bolivia (Vásquez et al. 2003: electronic supplement, Vásquez, et al. 2014), Chile (Novoa et al. 2015) and Argentina (Hauman 1920, Williams 1939).

Habitat and Ecology: Geophytes growing between 3100 to $4900 \mathrm{~m}$ of elevation (up to $5100 \mathrm{~m}, \mathrm{H}$. Trinidad pers. obs.) in wet places in the puna and paramo; plants of this genus are the only orchids growing in the high Andean wetlands.

Vargas (1995) proposed two subgenera in Myrosmodes: subgenus Myrosmodes and subgenus Rhynchocarpaea (Schltr.) C. Vargas. He suggested five floral characters to define the subgenus; however, here we consider that only three are reliable: perianth insertion on ovary, ovary morphology and lip morphology (perianth morphology and direction of petals and dorsal sepal are not useful features). Thus, subgenus Rhynchocarpaea has a perianth with oblique insertion on the ovary, ovary apex elongated into a variably long neck (Fig. 1F), and clawed lip with a cordate base. The Peruvian species included here are: Myrosmodes brevis (Schltr.) Garay and Myrosmodes rhynchocarpa (Schltr.) Garay (with its synonym here proposed: Myrosmodes cochlearis Garay). On the other hand, subgenus Myrosmodes does not have the perianth obliquely inserted on the ovary, apex of the ovary not rostrate and the lip sessile with a cuneate base. The Peruvian species included here are: Myrosmodes chiogena (Schltr.) C.A.Vargas, Myrosmodes gymnandra (Rchb.f.) C.A.Vargas, (with 

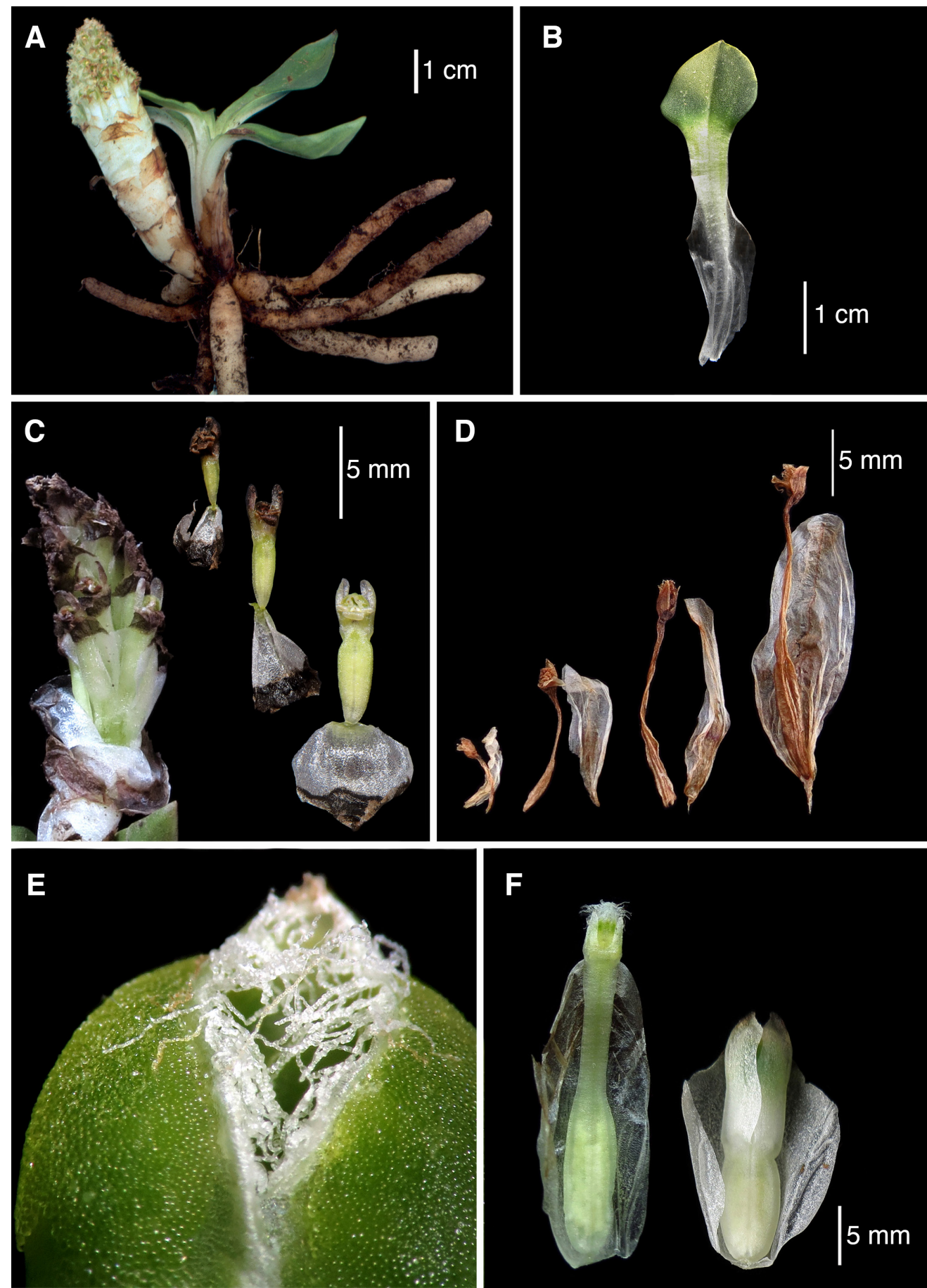

Figure 1. Vegetative and floral characters of Myrosmodes. A. Plant. B. Leaf. C. Inflorescence and flowers of different size, smaller from the apex and larger from the base. D. Dry flowers taken from a single inflorescence, smaller from the apex and larger from the base. E. Lip margin with moniliform hairs. F. Flowers with rostrate ovary (left) and a not rostrate ovary (right). Photographs A, C-F by D. Trujillo; B by P. Gonzáles. A, D, F-left Myrosmodes rhynchocarpa. C-Myrosmodes paludosa. E, F-right Myrosmodes gymnandra. 
its synonym here proposed: Myrosmodes weberbaueri (Schltr.) C.A.Vargas), Myrosmodes paludosa (Rchb.f.) P.Ortiz (with its synonyms here proposed: Myrosmodes inaequalis (Rchb.f.) C.A.Vargas and Myrosmodes pumilio (Schltr.) C.A.Vargas), Myrosmodes nubigena Rchb.f. (with its synonym here proposed: Myrosmodes cleefii Szlach., Mytnik \& S.Nowak,) and Myrosmodes nervosa (Kraenzl.) Novoa, C.A.Vargas \& Cisternas.

\section{Key to the Peruvian species of Myrosmodes}

1. Ovary long-rostrate at apex; lip clawed with a cordate base; perianth with oblique insertion on ovary

2. Column $3.0 \times 0.75 \mathrm{~mm}$; lip base distinctly clawed

2a. Column 1.5-3.0 x 1.0-1.8 mm; lip base shortly clawed M. rhynchocarpa

1a. Ovary not rostrate at apex; lip with a cuneate base; perianth insertion on ovary not oblique

3. Floral bract with the upper margin crenulate; petals with the upper margin lacerate-fimbriate; lip shallowly 3-lobed in front (or with a conspicuous midlobe); clinandrium margin dentate to lacerate M. nubigena

3a. Floral bract with the margin entire, undulate or somewhat irregular; petals entire or erose; lip simple or with a short midlobe; clinandrium margin entire

4. Lip with a short subquadrate midlobe

5. Dorsal sepal and petals revolute; dorsal sepal oblong; petals entire; lip elliptic to orbicular-ovate in outline; lip upper margins irregularly erose to shortly lacerate-fimbriate

M. chiogena

5a. Dorsal sepal and petals straight; dorsal sepal usually constricted in the middle; petals erose toward the apex; lip obovate to subquadrate in outline; lip upper margin with moniliform hairs $\quad$ M. gymnandra

4a. Lip simple without a short midlobe

6. Dorsal sepal narrowly oblong; petals entire; lip elliptical-obovate in outline

M. nervosa

6a. Dorsal sepal oblong to ovate-oblong; petals erose toward the apex; lip suborbicular in outline

\section{Species descriptions}

The following diagnoses were based upon the revision of type material, original description and illustrations, and the Peruvian specimens examined.

Myrosmodes brevis (Schltr.) Garay, Fl. Ecuador 9: 168. 1978.

Basionym: Aa brevis Schltr., Repert. Spec. Nov. Regni Veg., Beih. 9: 51. 1921.

TYPE: Peru. Lima [Junín, Prov. Yauli], alpine mats near Oroya, at the end of the Lima-Oroya Railway, [4000-] 4300 m., flowered November 1902. A. Weberbauer 1715 (holotype: B destroyed; lectotype: MOL-8281!, designated by Vargas 1995). (Fig. 2,3).

Plants small, $3 \mathrm{~cm}$ tall. Inflorescence 4.0$5.5 \mathrm{~cm}$ long, scape short, completely enclosed by densely imbricating, funnel-shaped sheaths; spike conical, 1.4-1.6 cm long. Floral bracts hyaline, sub-imbricate, suborbicular, irregular margin, little shorter than the flowers. Flowers minute. Dorsal sepal oblong, obtuse to rounded at apex, 3.3-4.0 × 1.2-1.5 $\mathrm{mm}$; lateral sepals basally connate, obliquely oblongelliptic, obtuse, $4.0-5.0 \times 1.3-2.0 \mathrm{~mm}$. Petals oblong-ligulate, acute to obtuse, margin irregular subdentate (as was, cited), 3.0-4.0 × 0.8-1.0 mm. Lip cucullate, clawed base, rhombic to orbicularovate when expanded (subquadrate in the original description), margin with moniliform hairs; two calli at the base, up to $3.5 \times 3.0 \mathrm{~mm}$. Column 3.0 $\times 0.75 \mathrm{~mm}$; rostellum truncate; stigma subquadrate. Ovary ellipsoid, long-rostrate, up to $4 \mathrm{~mm}$ long.

Distribution: Ecuador and Peru. In Peru it is known only from La Oroya in the Department of Junín (Fig. 4), between 4000 and $4300 \mathrm{~m}$ of elevation. This species was reported from Ecuador in the Provinces of Pichincha and Chimborazo, between 3600 and $3900 \mathrm{~m}$ of elevation (Garay 1978).

Habitat And ECOlOgY: This species has been reported in wetlands. Flowering in November.

The illustration of the lectotype showed here is based on one of the flowers kept in the envelope of the herbarium sheet (Fig. 2, 3). The flower illustrated 


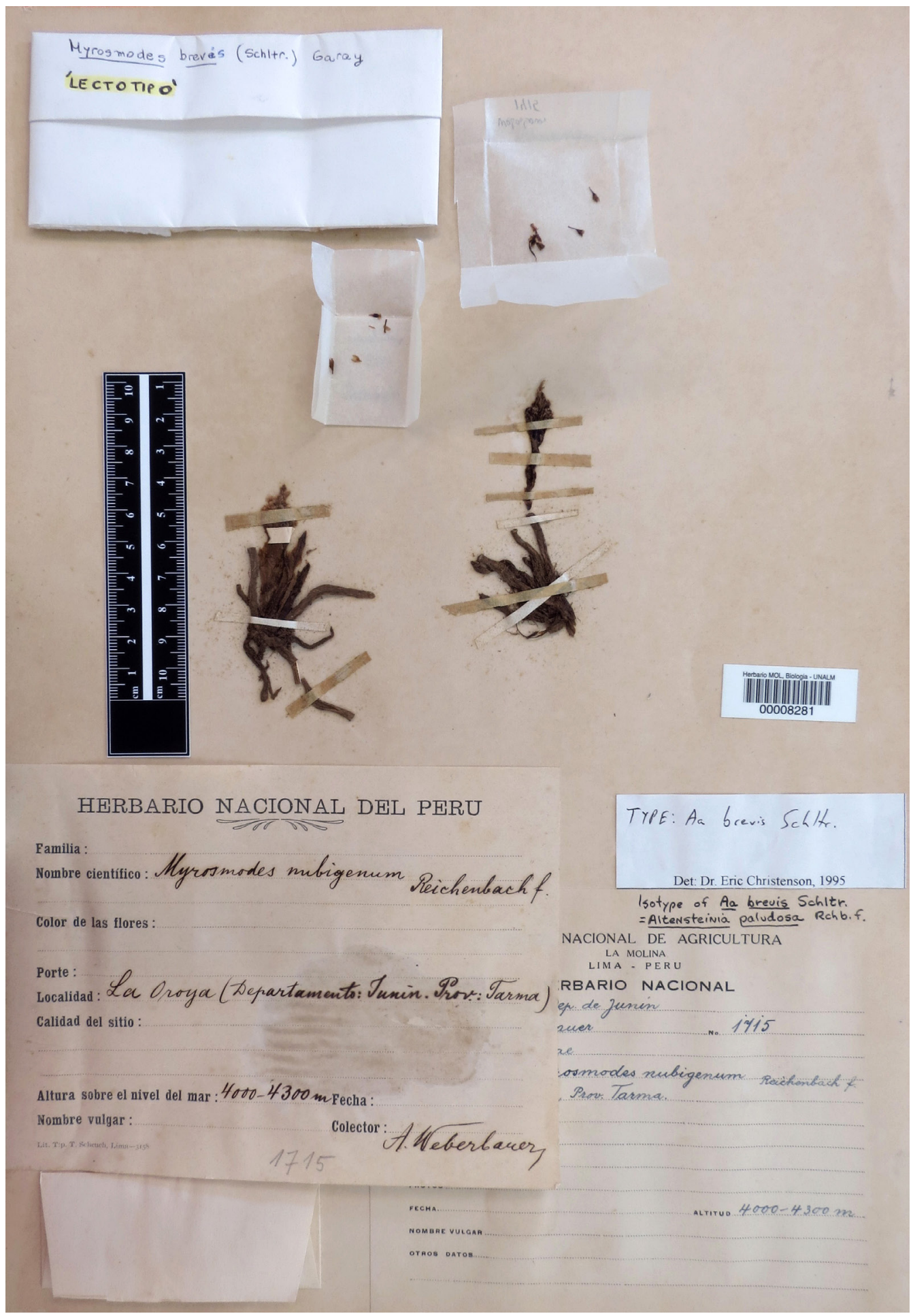

Figure 2. Myrosmodes brevis (Schltr.) Garay. Lectotype at MOL (A. Weberbauer 1715), by permission of the Keeper, Herbarium MOL, Biology Department, Universidad Nacional Agraria La Molina. 

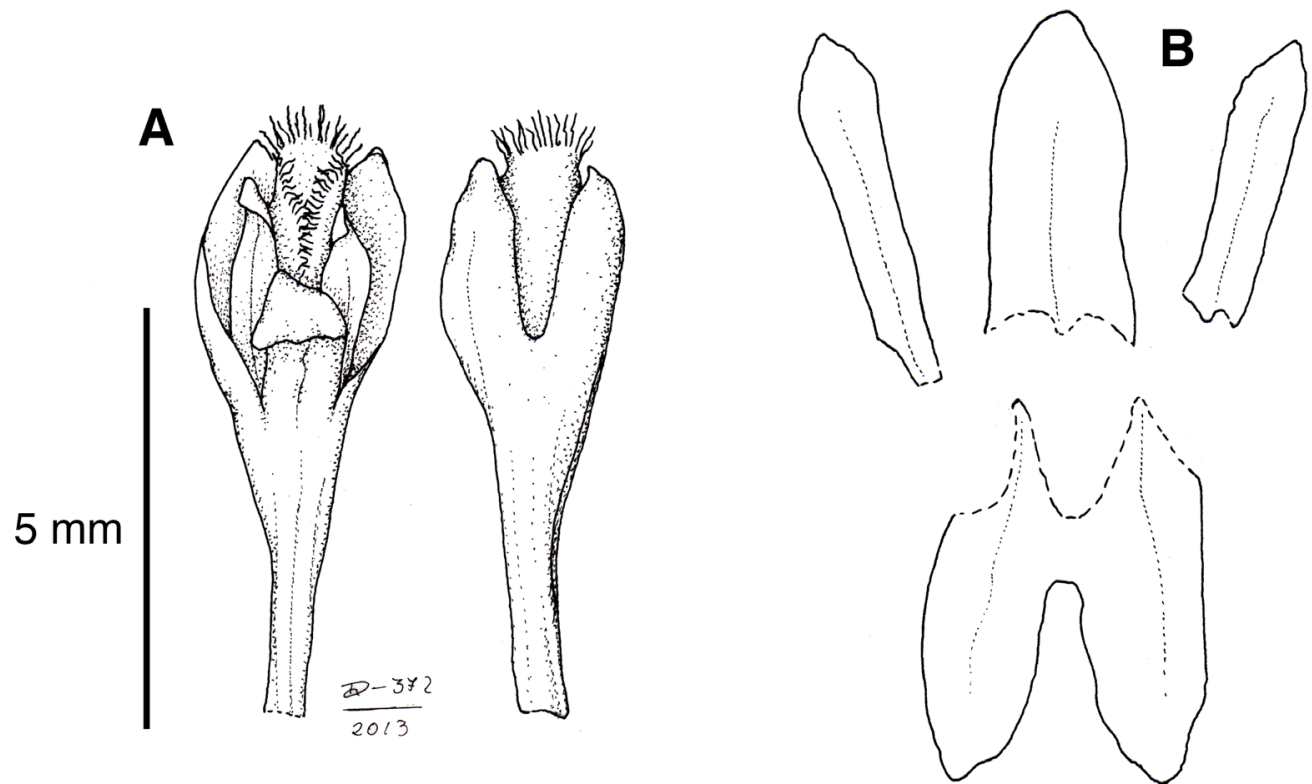

$3 \mathrm{~mm}$
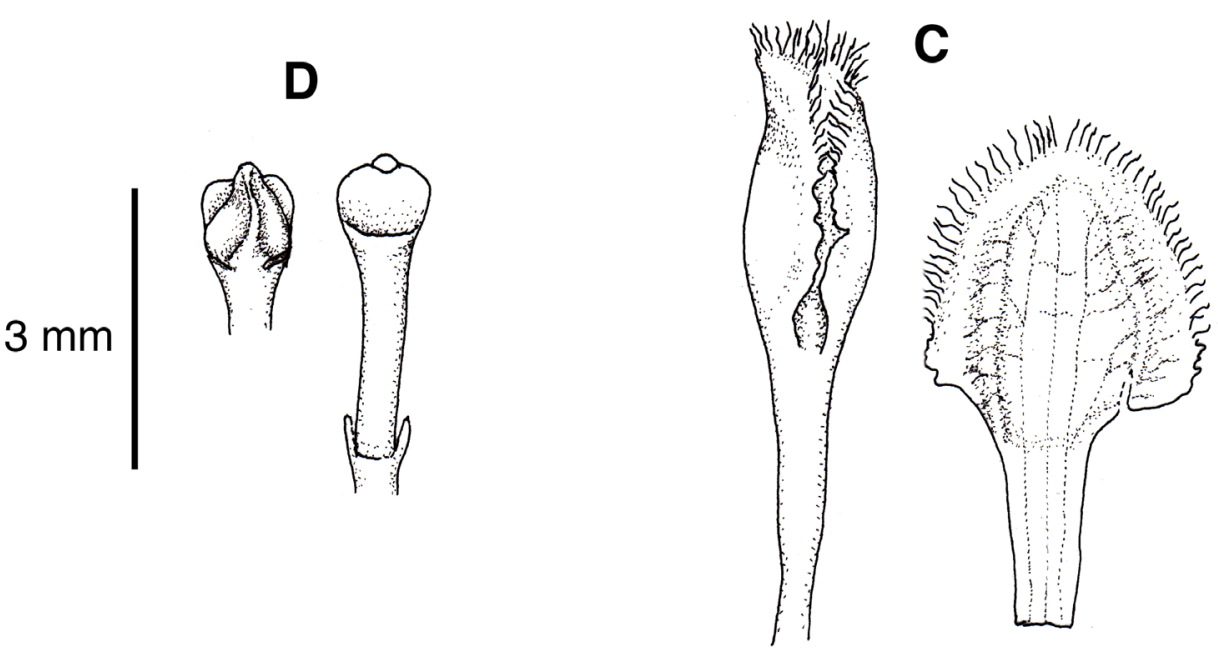

Figure 3. Myrosmodes brevis. A. Flower, ventral and dorsal view. B. Dissected perianth. C. Lip, natural (left) and expanded out (right). D. Column, dorsal and ventral view. Drawing by D. Trujillo based on A. Weberbauer 1715 (MOL).

from the lectotype (Fig. 3) showed three differences with the flower illustrated by Schlechter (published in Mansfeld 1929, plate 105, nr. 410): the petals margins are not irregular dentate (just slightly irregular on the apex), the calli on the base of lip are not evident and lip is orbicular-ovate instead of rhombic.

Schweinfurth (1958) placed this species as a synonym of Altensteinia [Myrosmodes] paludosa
Rchb.f.: however, they represent different species. Myrosmodes brevis can be distinguished from $M$. paludosa by its long-rostrate ovary, clawed base lip, and a thin and relatively longer column $(3.0 \mathrm{~mm}$ long vs. $2.2 \mathrm{~mm}$ in M. paludosa).

Myrosmodes brevis is similar to M. rhynchocarpa (both belong to the subgenus Rhynchocarpaea) from which it differs by its long and thin column, and lip base distinctly clawed. 


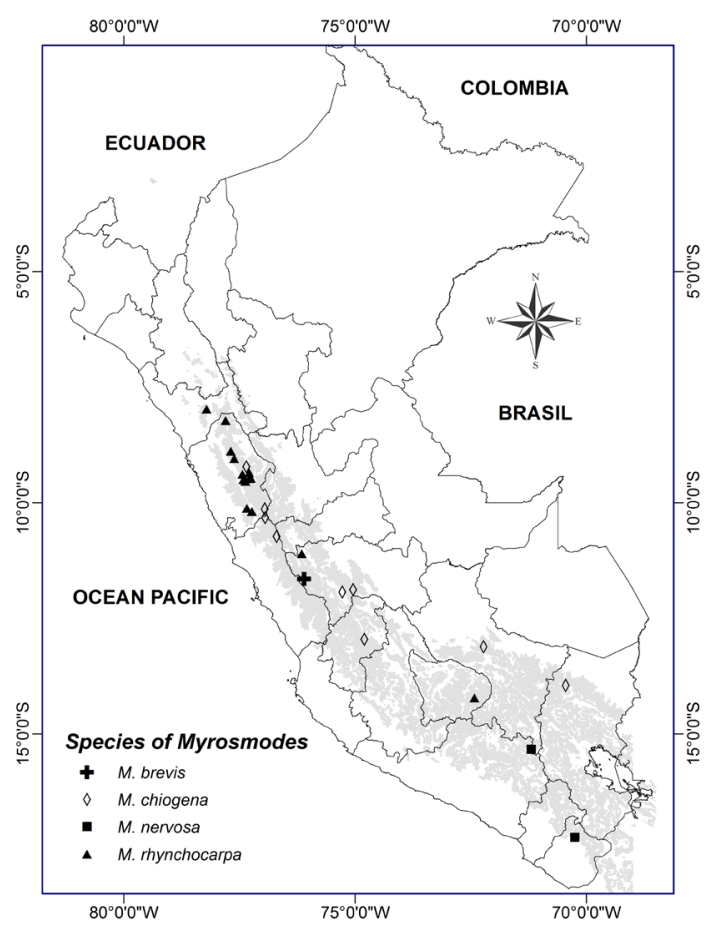

FIGURE 4. Distribution map of Myrosmodes brevis, M. chiogena, M. nervosa and M. rhynchocarpa in Peru.

\section{Myrosmodes chiogena (Schltr.) C.A.Vargas,} Lindleyana 10: 6. 1995.

Basionym: Aa chiogena Schltr., Repert. Spec. Nov. Regni Veg. Beih. 10: 35. 1922.

Altensteinia chiogena (Schltr.) C.Schweinf., Bot. Mus. Leafl. 16: 2. 1953.

TYPE: Bolivia. La Paz, in Chacaltaya, 30 $\mathrm{km}$ from La Paz, $4800 \mathrm{~m}$, February 1908. $O$. Buchtien 1289 (holotype: B, destroyed; isotype: HBG-500204, photo seen, designated here as the lectotype).

Plant small, $1.8-5.0 \mathrm{~cm}$ tall. Inflorescence 3.5 $7.8 \mathrm{~cm}$ long (up to $10 \mathrm{~cm}$ during fruit maturation), scape completely enclosed by hyaline imbricating, loosely infundibuliform sheaths; spike cylindricalconic, 1.2-3.0 cm long, 13-18 flowers. Floral bracts hyaline, suborbicular-ovate, obtuse to rounded at the apex, with irregular margins, subequaling the flowers. Flowers small, white with green (Fig. 5A). Dorsal sepal oblong, obtuse or rounded at the apex, revolute, $3.5-5.4 \times 1.2-2.8 \mathrm{~mm}$. Lateral sepals basally connate, obliquely oblong, obtuse, 4.4-7.5 x 1.2-2.9 mm.
Petals linear, obtuse to rounded at the apex, more or less falcate, revolute, with the upper margin entire or irregular, 3.0-6.0 × 0.3-1.0 mm. Lip cucullate, cuneate at base, hemispheric-ovate, elliptic to orbicular-ovate when expanded, with a short subquadrate midlobe (rarely absent), the upper margins irregularly erose to shortly lacerate-fimbriate, with two small calli at the base, $3.9-7.0 \times 3.2-5.5 \mathrm{~mm}$, midlobe $0.3-1.0$ $\times 1.6 \mathrm{~mm}$. Column short, dilated above, $2.0-3.5 \times$ $1.0-1.9 \mathrm{~mm}$; rostellum truncate, slightly emarginate; stigma oblong-quadrate to transverse (in old flowers examined). Ovary elliptic, 5.0-8.0 mm long (Fig. 6).

Specimens examined: Peru. Ancash, Prov. Huaraz, Huascaran National Park, Quebrada Llaca, NW side of valley, 4400-4600 m, lateral moraine; grassland and open Polylepis weberbaueri Pilg. woods, terrestrial from fleshy roots, infl tan, 24 May 1985, D. Smith et al. 10801 (USM-69778). Prov. Bolognesi, Cochacutan, alrededores de la primera laguna de Jahuacocha, $5200 \mathrm{~m}$ [4100-4500 m], puna, playa pedregosa, 28 May 1954, E. Cerrate 2306- $a$ (USM-263093). Lima, Prov. Cajatambo, Distrito de Copa, Coramarca cerca a Nevado Yerupajá, $4400 \mathrm{~m}$, puna, bofedal, hierba, acaule, inflorescencia blanca, el eje florífero da la apariencia de pequeña esponja, 20 Apr 1998, C. del Carpio 2943 (MOL). Prov. Oyón, Distrito Oyón, Uchucchacua, 4450-4470 m, ladera pedregosa con suelo franco, pajonal alto, $1 \mathrm{Feb} 2014$, A. Cano et al. 21837 (USM). Junín, Prov. Huancayo, Distrito El Tambo, Acopalca, lagunas Quimsaycocha y Quellaocha, 4478-4621 m, ladera con suelo inundado y bofedales, hierba de $8 \mathrm{~cm}$, inflorescencia senescente verde pálido, 14 May 2011, D. Rodriguez 393 (USM291424). Prov. Huancayo, Distrito Huancayo, alrededores de la Laguna Lasuntay, entre la quebrada Anlayaco y el nevado Huaytapallana, 4595-4669 m, en bofedales, 15 May 2011, D. Rodriguez 600 (USM291455). Huancavelica, Prov. Angares, Ccochaccasa, 4320-4330 m, ladera con suelo franco; pajonal bajo, 4 May 2014, A. Cano et al. 21912-a (USM). Puno, Prov. Carabaya, Distrito Macusani, Pacaje - Chacopata, 4897 $\mathrm{m}$, vegetación de suelo crioturbado, 17 Mar 2014, P. Gonzáles 3057-b (USM).

Other Records: Peru. [Cusco], Piñasniocj, Panticalla Pass, about 3600 m, 18 Jun 1915, Cook \& Gilbert 1306 (US, not seen; photo at AMES) (cited by Schweinfurth 1958). 

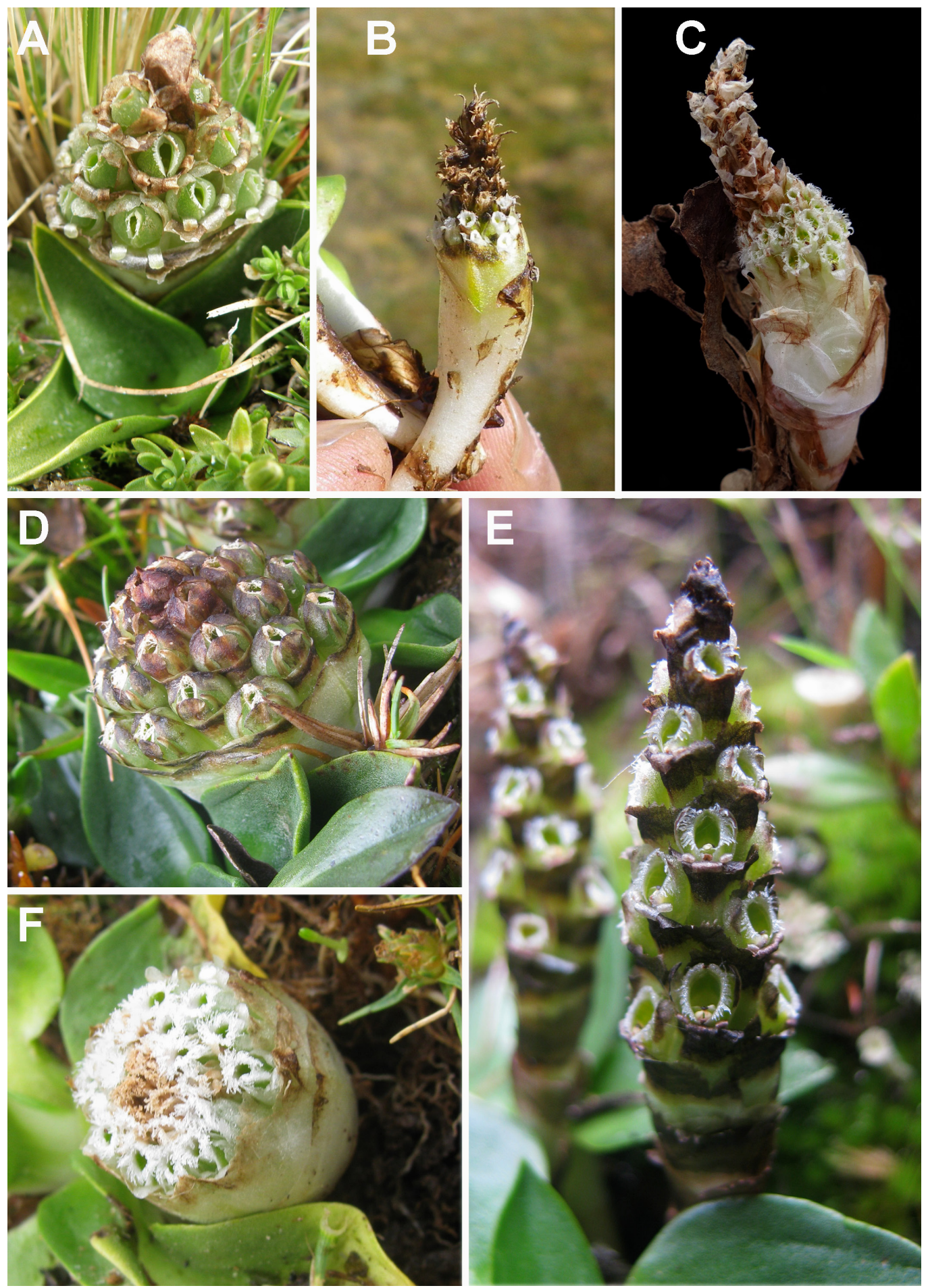

Figure 5. Inflorescences of Myrosmodes. A. Myrosmodes chiogena. B. Myrosmodes nubigena. C. Myrosmodes rhynchocarpa.

D. Myrosmodes gymnandra. E Myrosmodes paludosa. F. Myrosmodes nervosa. Photographs A by P. Gonzáles; B by A. Cano; C by D. Trujillo; D, E, F by H. Trinidad. 

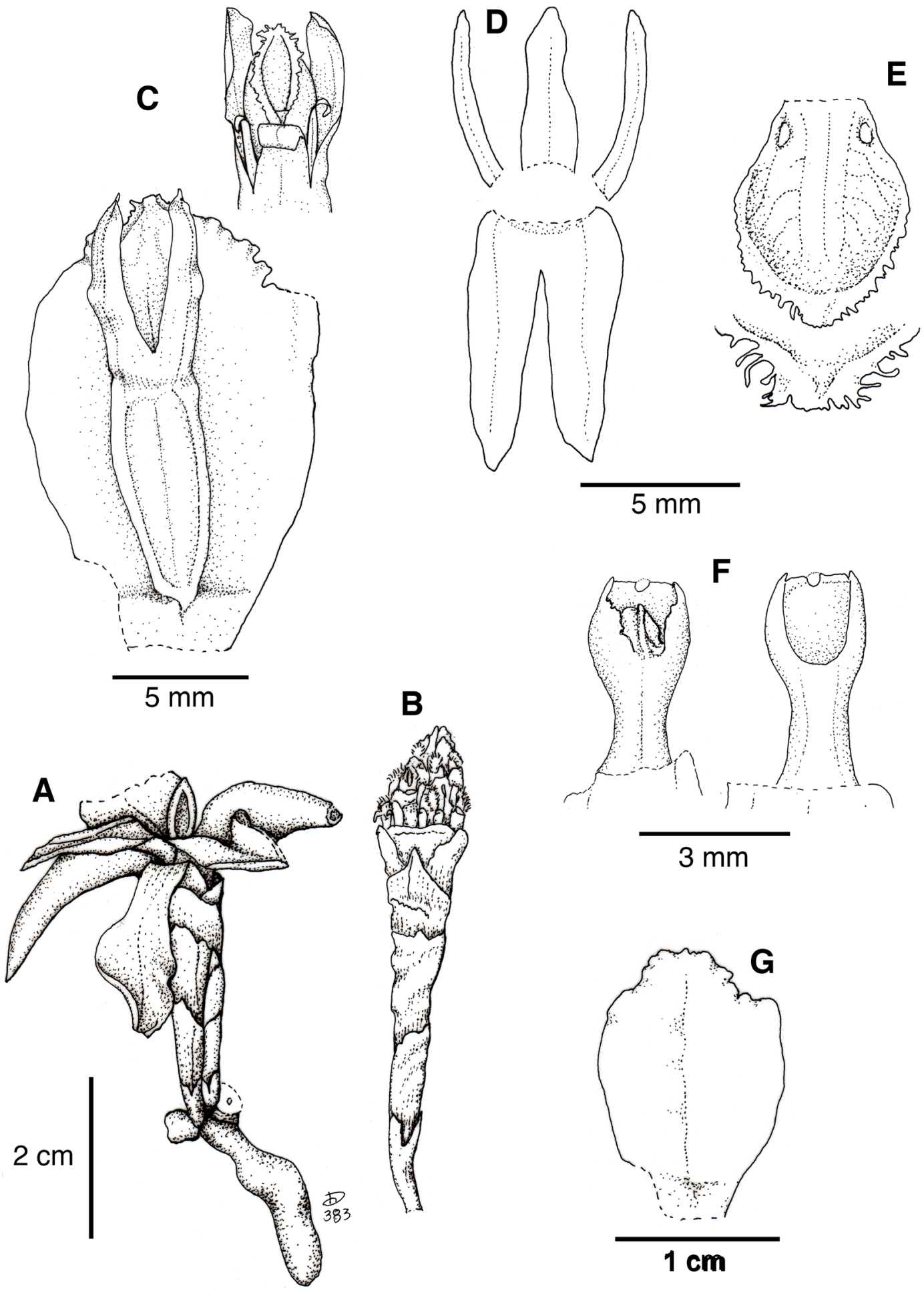

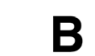

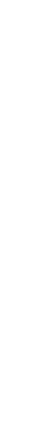


Distribution: Peru and Bolivia. In Peru it is known in the Departments of Ancash, Lima, Junín, Huancavelica, Cusco and Puno (Fig. 4), between 3600 and $4900 \mathrm{~m}$ elevation. In Bolivia it is known only from $\mathrm{La} \mathrm{Paz} \mathrm{(the}$ type locality).

Habitat and ecology: Plants of this species grow on rocky hillsides with loam soil, grasslands, wetland and in cryoturbated soils (high Andean mixing of soil due to frequent freezing and thawing). Flowering from February to May.

\section{Myrosmodes gymnandra (Rchb.f.) C.A. Vargas,} Lankesteriana 11: 5. 2011.

Basionym: Altensteinia gymnandra Rchb.f., Xenia Orchid. 3: 18. 1878.

TYPE: Bolivia. Prov. Larecaja, G. Mandon s.n. (holotype: W-23376!).

Aa gymnandra (Rchb.f.) Schltr., Repert. Spec. Nov. Regni Veg. 11: 150. 1912

Synonym: Myrosmodes weberbaueri (Schltr.) C.A.Vargas, Lindleyana 10: 6. 1995. syn. nov. Aa weberbaueri Schltr., Repert. Spec. Nov. Regni Veg. Beih. 9: 53. 1921. Altensteinia weberbaueri (Schltr.) C.Schweinf., Bot. Mus. Leafl. 16: 2. 1953. TYPE: Peru. Lima [Junín], Near Jauli [Yauli], 4400 meters, alpine mats of the Hacienda Arapa, A. Weberbauer 283 (holotype: B, destroyed).

Plant small, 3.0-6.8 cm tall. Inflorescence 4.3-8.0 $\mathrm{cm}$ long (10.0-17.0 $\mathrm{cm}$ long during fruit maturation), scape covered by broad hyaline sheaths, obtuse, somewhat mucronate, spike conic to cylindricalconic, $1.0-4.0 \mathrm{~cm}$ long, $14-27$ flowers. Floral bracts suborbicular-ovate, obtuse to rounded at the apex, with entire margins, shorter than the flowers, $10.7-18.0 \mathrm{x}$ 10-18 mm. Flowers small, sepals and petals whitehyaline with the apex turning brown, lip green with white at the base and margin (Fig. 1E, 5D). Dorsal sepal adnate to the column near the base, straight, oblong, usually slightly constricted in or above the middle, obtuse or rounded at the apex, 5.0-8.0 $\times 1.4-2.6 \mathrm{~mm}$. Lateral sepals connate at the base (slightly to up half their length), oblong, concave, obtuse to subacute, sometimes apex slightly erose, somewhat carinate, $6.0-9.5 \times 2.0-4.5 \mathrm{~mm}$. Petals straight, linear, subacute, more or less falcate, with upper margin erose, 5.0-8.5 $\times 0.6-1.1 \mathrm{~mm}$. Lip cucullate, obovate to subquadrate with a short subquadrate midlobe, the upper margin with moniliform hairs, two calli at the base, 5.8-9.5 $\times$ 5.0-9.5 mm, midlobe 0.8-1.0 $\times 0.8-1.0 \mathrm{~mm}$. Column erect, 3.0-7.5 × 1.0-2.0 mm. Anther 0.9-1.8 mm long, sometimes exceeding the apex of the stigma; rostellum narrow emarginate (sometimes triangular and obtuse); stigma elliptic to oblong-quadrate. Ovary ellipsoid, 5-11 mm long (Fig. 7).

Specimens examined: Peru. Ancash, Prov. Carhuaz, Huascaran National Park, Quebrada Ishinca, side valley to Laguna Ishinca, $4700 \mathrm{~m}$, Distichia muscoides Nees \& Meyen bog; NE-facing gentle slopes, moist grassland, 16 Jul 1985, D. Smith \& M. Buddensiek 11187 (USM-104507). Prov. Carhuaz, Huascaran National Park, Quebrada Honda, between Vinoyapampa and Portachuelo Honda, 4200-4400 m, natural grassland, steep slopes, various aspects, terrestrial, wet spot, 3 Oct 1985, D. Smith et al. 11674 (USM-73717). Prov. Huaraz, 4320-4350 m, oconal, suelo arcilloso, inundado y pequeños charcos, dominancia de Plantago rigida Kunth hierba escasa, 10 Oct $2001 \mathrm{~A}$. Cano et al. 11837 (USM-175871). Prov. Huari, Chavín de Huantar, road from Chavín de Huantar to Catac, 4500-4650 m, steep, SW-facing slope with large rock-outcrops and permanent watercourse plus seepage areas, in deep Distichia muscoides-cushions, 10 Oct 2007, M. Weigend et al. 07/159 (USM-224881). Prov. Recuay, Distrito Catac, Laguna de Conococha, 3990 m, suelo inundado, bofedal, hierba, terrestre, escasa, flores blancas, $4 \mathrm{Jul}$ 2011, $A$. Cano \& H. Trinidad 20524 (USM). Collado sobre rio Punapampa, 4550 m, Puna, 18 Mar 1983, O. Tovar et al. 9637, (USM). Lima, Prov. Oyón, Distrito Pachangara, Iscaycruz, $4698 \mathrm{~m}$, ladera de pendiente muy suave $\left(5^{\circ}\right)$, suelo inundado, bofedal, $31 \mathrm{Jul}$ 2014, A. Cano \& $N$. Valencia 22155 (USM). [Prov. Canta], between Culnai [Culluhay] and Obrajillo, 1838-1942, Wilkes Expedition s.n, (W-23376, in part, GH-7353, photo seen,). Prov. Yauyos, Distrito Miraflores, Uman, 4476 m, ladera y planicie con suelo inundado, bofedal, hierba escasa, 16 Apr 2015, A. Cano et al. 22250 (USM). Pasco, Prov. Daniel A. Carrión, Caballococha, 4780-4800 m, ladera y planicie con suelo saturado, bofedal, $8 \mathrm{Feb} 2014, A$. Cano et al. 21815 (USM). Junín, Prov. Junín, Ondores, 4300 m, Pampa pedregosa, 13 Sep 1976, U. Pettersson 153 [in part] (USM-167406). Huancavelica, Prov. Huancavelica, Distrito Huachocolpa, Esperanza, 4420 

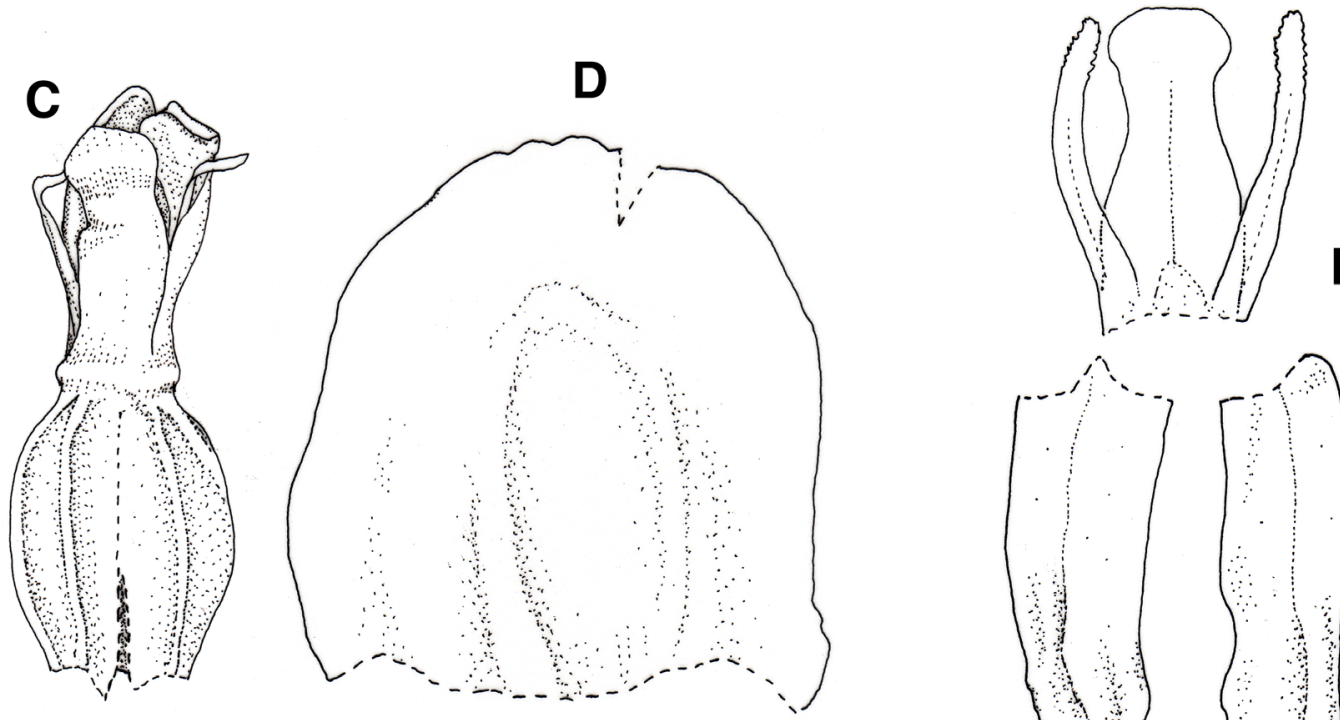

$\mathbf{E}$
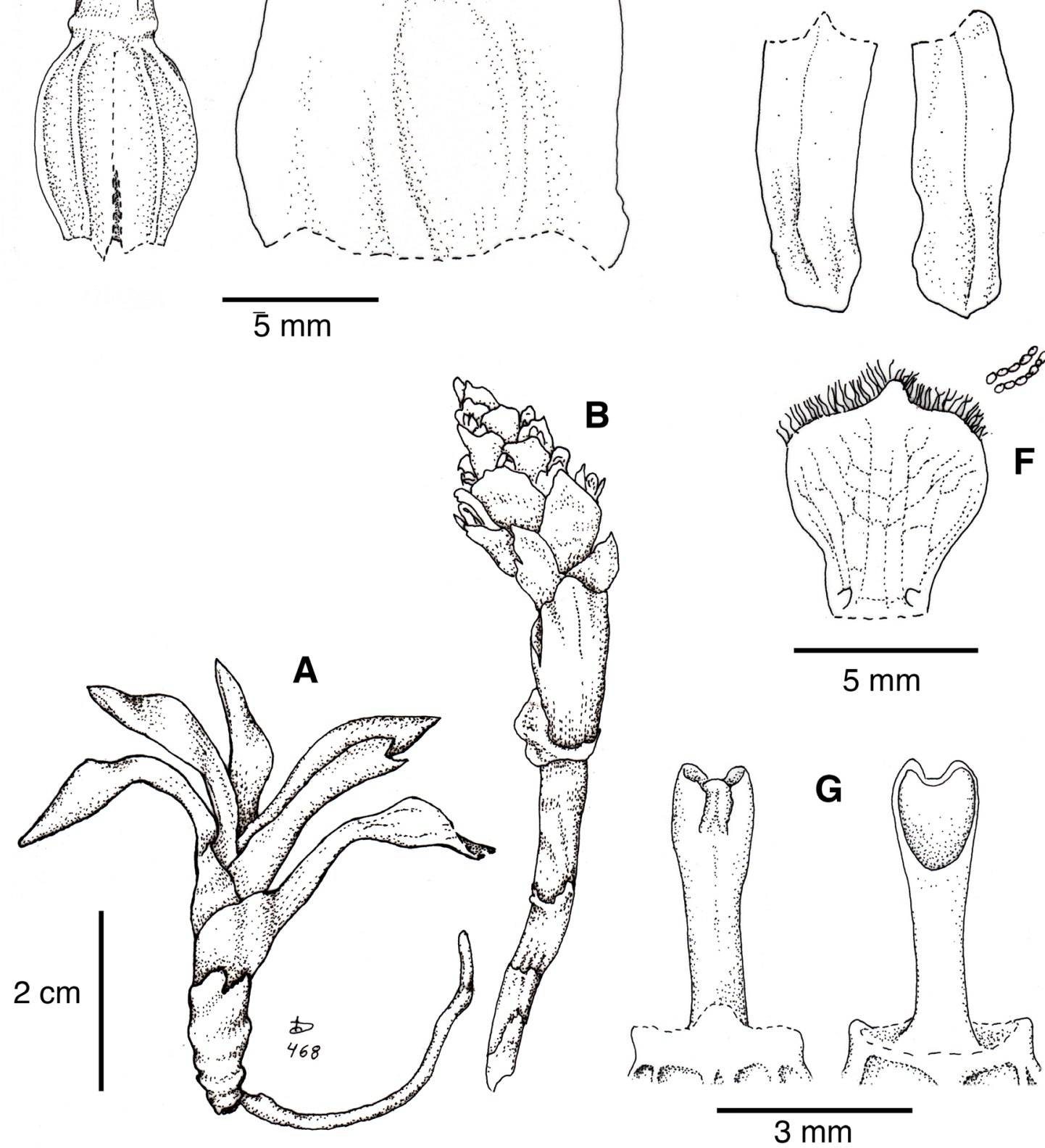

Figure 7. Myrosmodes gymnandra. A. Habit. B. Inflorescence. C. Flower. D. Floral bract. E. Dissected perianth. F. Lip. G. Column, dorsal and ventral view. Drawing by D. Trujillo based on W. Ramirez 1035. 
$\mathrm{m}$, pajonal de puna, dominado por gramíneas, hierba en pajonal, flores verdosas, 16 Jun 2007, H. Beltrán 6389 (USM-224834). Arequipa, Prov. Castilla, Distrito Orcopampa, Minas de Paracota, quebrada Yuraccarcca, $4643 \mathrm{~m}$, bofedal dominado por Distichia muscoides, sobre pastoreado, hierba flores verde blanquecinas, 20 Apr 2011, H. Beltrán 7092 (USM-246337). Cusco, Prov. Anta, Distrito de Mollepata, 4000 m, pajonal, hierba con flores blanco-verdosas 12 May 2013, $H$. Beltrán 7704 (USM-277960). Puno, Prov. Carabaya, Corani, Chacaconiza, $4458 \mathrm{~m}$, bofedal, hierba escasa, 2-3 cm flores blancas 14 Mar 2014, P. Gonzáles 2996 (USM).

Other records: Peru. Huánuco, Cordillera Raura, Oct 2011, A. Cano s.n. Huancavelica, Prov. Huancavelica, Distrito Huachocolpa, unidad minera Recuperada, 4416 $\mathrm{m}$, bofedal ubicado en una planicie en el fondo del valle sobrepastoreado, suelo húmedo a saturado, hidrología temporal, vegetación dominada por Aciachne sp., Distichia muscoides, hierba escasa, en floración, frutos, 23 Jun 2014, W. Ramírez 1035. Moquegua, Prov. Mariscal Nieto, Poblado Chilota-Lepiche, $4391 \mathrm{~m}$, bofedal ubicado en una planicie ligeramente ondulada, de suelo inundado-saturado, vegetación dominada principalmente por almohadillados de Oxychloe andina Phil. seguido de Distichia muscoides, especies acompañantes: Calamagrostis eminens (J. Presl) Steud. y Calamagrostis rigescens (J. Presl) Scribn., hierba, escasa, en floración, la especie suele crecer entre las hojas de Oxychloe andina, 2 May 2013, W. Ramírez \& D. Rodríguez 1032.

Distribution: Peru, Bolivia and Argentina. In Peru it is known in the Departments of Ancash, Huánuco, Lima, Pasco, Junín, Huancavelica, Arequipa, Cusco, Puno and Moquegua (Fig. 8); between 3990 and $4800 \mathrm{~m}$ elevation. In Bolivia it is known only from the Province of Larecaja (the type locality). In Argentina, Provinces of Jujuy and Catamarca, it seems that this species has been erroneously determined as $M$. paludosa (see notes below, on M. paludosa).

Habitat And ecology: Plants of this species grow in wetland dominated by Distichia muscoides, Oxychloe andina. or Plantago rigida; and occasionally in grasslands of gentle and steep slopes. Flowering plants have been recorded from February to April and from June to October, and fruiting between May to July.

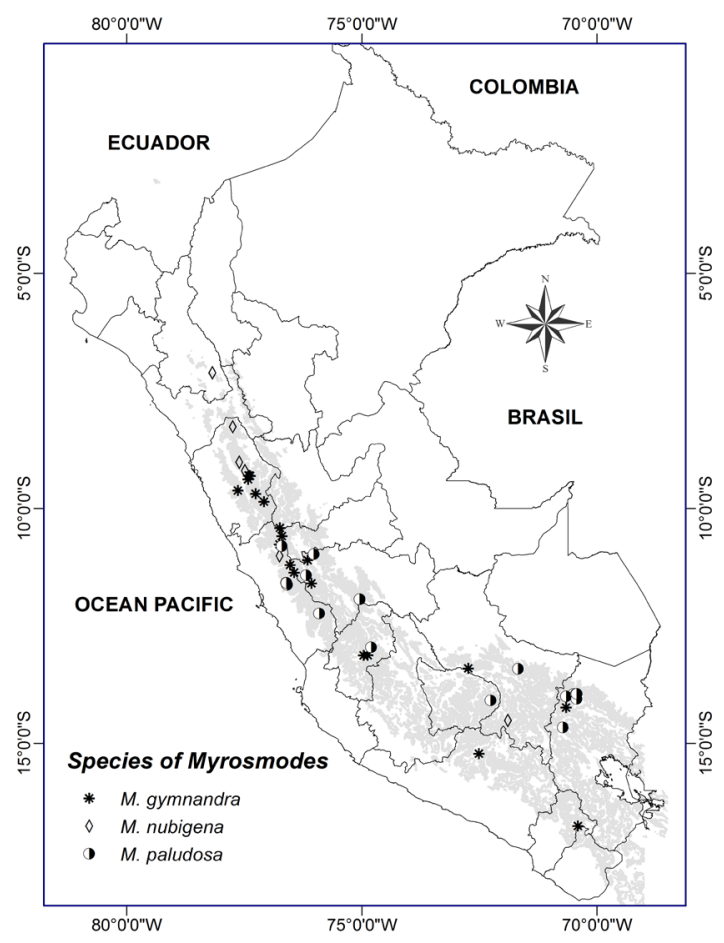

Figure 8. Distribution map of Myrosmodes gymnandra, $M$. nubigena and M. paludosa in Peru.

Variations in the width of sepals and length of the midlobe of the lip have been observed in the Peruvian specimens of M. gymnandra. This species can be easily distinguished from all other species of the genus by the long column, the straight dorsal sepal (never revolute) and lip with a narrow opening.

Myrosmodes weberbaueri was described from the Central Peru by Schlechter (1921). Although the holotype (A. Weberbauer 283) was lost when part of Berlin herbarium was destroyed in the Second World War, an illustration by Schlechter based on the type was published by Mansfeld (1929, plate 105, nr 413). The illustration shows a tridentate rostellum. However, in the original description, Schlechter cited "rostelo, alto, oblongo" but not tridentate. Hence, here we assume that this is an artifact. Except for the rostellum, M. weberbaueri resembles to $M$. gymnandra. We therefore refer this taxon to the synonymy of $M$. gymnandra.

A specimen of the Wilkes Expedition from Peru (determined as M. gymnandra by Reichenbach) is mounted together with the holotype (Mandon s.n.) on 
a single sheet in the Reichenbach Herbarium at Vienna (W) (see Trujillo \&Vargas 2011). A duplicate of this Wilkes specimen is also kept at GH.

Myrosmodes nervosa (Kraenzl.) Novoa, C.A. Vargas \& Cisternas, Gayana Bot. 72: 152. 2015.

Basionym: Altensteinia nervosa Kraenzl., Bot. Jahrb. Syst. 36 (3, Beibl. 80): 8. 1905.

TYPE: Chile. Prov. Tarapacá, Taruguire, 3750 m, R. Pohlmann s.n. (holotype: B destroyed; lectotype: SGO-01328, designated by Novoa et al. (2015).

Aa nervosa (Kraenzl.) Schltr., Repert. Spec. Nov. Regni Veg. 11: 150. 1912.

Plant small, $2.5-5.0 \mathrm{~cm}$ tall. Inflorescence $3.0 \mathrm{~cm}$ long (up to $16.0 \mathrm{~cm}$ long during fruit maturation), scape covered by broad hyaline sheaths, spike thick, conic, $1.4 \mathrm{~cm}$ long (up to $4.0 \mathrm{~cm}$ long during fruit maturation), around 21 flowers. Floral bracts ovate to oblong, acute, with entire margin, same size or little shorter than the flowers, $15.2-15.6 \times 11.2-12.8 \mathrm{~mm}$. Flower small, white-hyaline with green (Fig. 5F). Dorsal sepal narrowly oblong, obtuse or rounded at the apex, deflexed, 4.5-5.2 × 1.3-1.4 mm. Lateral sepals basally connate for one-quarter their length, oblong, obtuse, $5.0-5.4 \times 1.3-1.8 \mathrm{~mm}$. Petals linear, obtuse to subacute, $4.3-4.8 \times 0.7-0.8 \mathrm{~mm}$. Lip slightly cucullate-concave, elliptical-obovate in outline, the upper margin with moniliform hairs, two calli at the base, 4.5-6.0 $\times 2.8-$ $3.5 \mathrm{~mm}$. Column $2.9-3.0 \times 1.0 \mathrm{~mm}$. Anther $1.2-1.7 \mathrm{~mm}$ long; rostellum truncate, slightly emarginate; stigma quadrate. Ovary ellipsoid, 7.0-10.5 mm long (Fig. 9).

Specimens examined: Peru. Tacna, Prov. Candarave, Volcan Yucamani, 3100-3400 m, quebrada y oconal, escasa, 9 Dec 1997, M. I. La Torre 2031 (USM159420).

Other ReCORDs: Peru. Arequipa, 4900 m, Sept 2012, H. Trinidad s.n.

Distribution: Peru and Chile. In Peru it has been recorded in the Departments of Arequipa and Tacna (Fig. 4), between 3100 and 4900 m elevation. In Chile it is known in the Regions of Arica and Parinacota, Tarapacá and Antofagasta (Novoa et al. 2015).

Habitat And ecology: Plants of this species grow in wetland. Flowering from September to November, and fruiting in December.
This is the first record of M. nervosa for Peru, which was recorded in the past only for Northern Chile (Novoa et al. 2015).

Myrosmodes nubigena Rchb.f., Xenia Orchid. 1: 19. 1854.

TYPE: Ecuador. Pichincha, $15,500 \mathrm{ft}$, where it is frequently covered with snow, [1849], Jameson 816 (holotype: G-168830 (ex Herb. Barbey-Boissier), isotype G-168831).

Altensteinia nubigena (Rchb.f.) Rchb.f., Xenia Orchid. 3: 18. 1878.

Aa nubigena (Rchb.f.) Schltr., Repert. Spec. Nov. Regni Veg. 11: 150. 1912.

Synonym: Myrosmodes cleefii Szlach., Mytnik \& S.Nowak, P1. Syst. Evol. 298: 1911 (2012). syn. nov. TYPE: Colombia. Meta: Paramo de Sumapaz. Cerro Nevado del Sumapaz, superparamo. Pico del Nevado, 4300 m, 30 Jan 1972, A. M. Cleef 1298 (holotype: COL, not seen).

Plant small, 1.7-3.5 cm tall. Inflorescence 3.0-8.0 $\mathrm{cm}$ long (up to $13.0 \mathrm{~cm}$ long during fruit maturation), scape covered by tubular hyaline sheaths which are obtuse and somewhat carinate, spike conic or cylindric-conic, $1.0-2.4 \mathrm{~cm}$ long (up to $3 \mathrm{~cm}$ long during fruit maturation), around 13 to 29 flowers (Fig. 5B). Floral bracts suborbicular to ovate, acute, crenulate above, a little shorter than the flowers, 10.0-12.0 × 7.0-8.6 mm. Flowers small. Dorsal sepal adnate to the column near the base, ovate to oblong-obovate, rounded to acute, somewhat carinate at the apex, deflexed, 3.3-5.4 × 1.0-2.4 mm. Lateral sepals basally connate, obliquely oblong, acute, apex minutely erose, somewhat carinate, 3.6-7.0 × 1.0-3.0 $\mathrm{mm}$. Petals obliquely linear or linear-spatulate, with the upper margins lacerate-fimbriate, $2.8-5.8 \times 0.6-1.2$ $\mathrm{mm}$. Lip cucullate, cuneate, quadrate in outline when expanded, shallowly 3-lobed in front with rounded infolded lateral lobes and suborbicular-ovate midlobe, the anterior margins with dense moniliform hairs; two calli at the base, $4.0-5.6 \times 2.5-5.6 \mathrm{~mm}$, midlobe 0.8 $0.9 \times 0.5-1.0 \mathrm{~mm}$. Column slender, dilated above, $2.5-3.5 \times 0.6-1.3 \mathrm{~mm}$, clinandrium winged, wings (margin) dentate to lacerate; rostellum truncate; stigma subquadrate. Ovary $4.6-7.0 \mathrm{~mm}$ long (Fig. 10).

LANKESTERIANA 16(2). 2016. (C) Universidad de Costa Rica, 2016. 


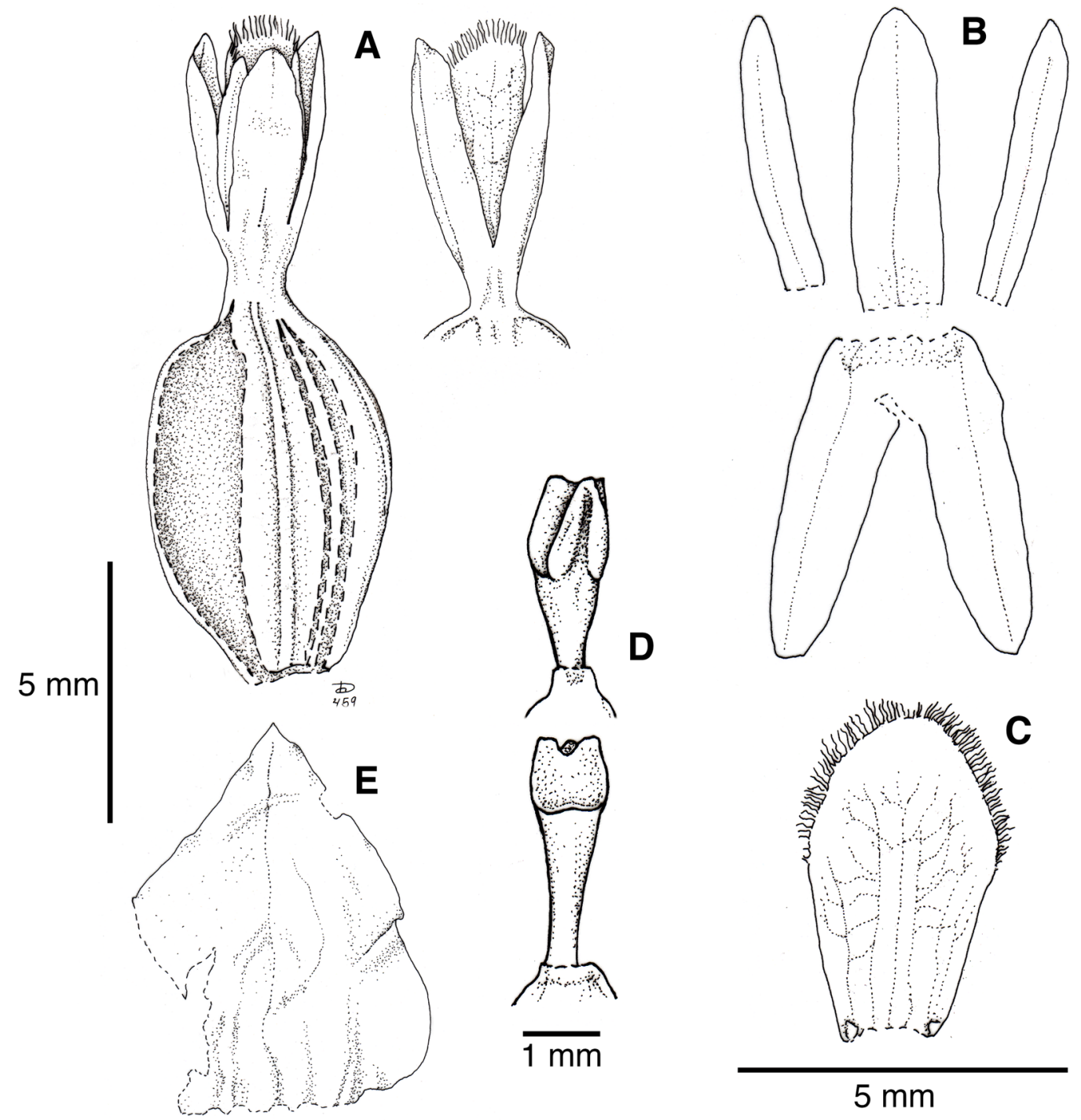

Figure 9. Myrosmodes nervosa. A. Flower, dorsal and ventral view. B. Dissected perianth. C. Lip. D. Column, dorsal and ventral view. E. Floral bract. Drawing by D. Trujillo based on M. La Torre 2031 (USM).

Specimens examined: Peru. Ancash, Prov. Yungay, Distrito Yungay, Chracca Pampa, 4384-4385 m, planicie con suelo muy húmedo y riachuelos, bofedal y pajonal alto, 9 Jul 2013, A. Cano \& M. Polk 21570 (USM).

Prov. Pallasca, Distrito Conchucos, Challhuacocha, 4219 m. 1 May 2012, A. Cano et al. 21098 (USM). Prov. Asunción. Distrito Chacas, alrededores de la Laguna Lebrón, 4500-4800 m, ladera de rocas y morrenas glaciares, abundancia de filtraciones y zonas húmedas, bosque de Polylepis y pajonal ralo, 20 May 2009, A. Cano et al. 19304 (USM). Lima, Prov. Oyón,
Distrito Pachangara, Iscaycruz, 4698 m, ladera de pendiente muy suave $\left(5^{\circ}\right)$, suelo inundado, bofedal, Aug 2014, A. Cano \& N. Valencia 22154 (USM).

Other ReCords: Peru. Cajamarca, Prov. Celendin, Combayo, Mishacocha, $3700 \mathrm{~m}$, pajonal, pendiente $30^{\circ}$, hierba frecuente, con frutos, 17 Sept 2006, W. Mendoza 4397. Cusco, Prov. Chumbibilcas, Distrito Velille, arriba de Chilloroya, debajo de laguna Cutinacocha, $4400 \mathrm{~m}$, bofedal, hierba, escasa, flores blancas, 25 Apr 2016, P. Gonzáles \& K. Ccollana 3957. 


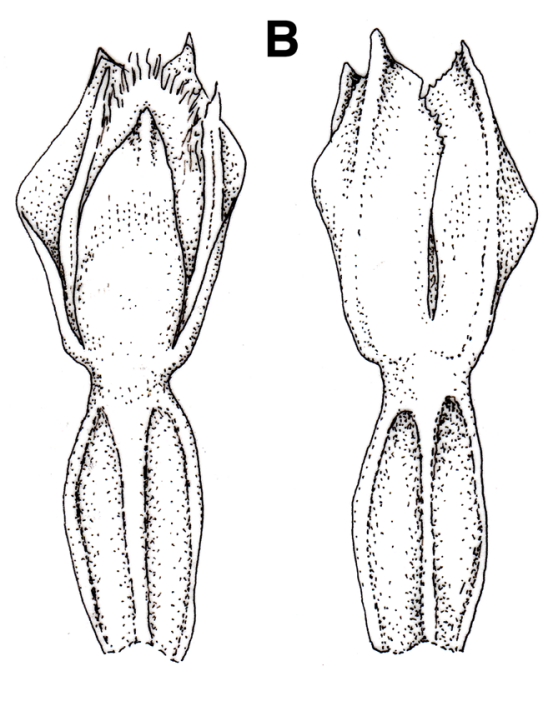

$5 \mathrm{~mm}$

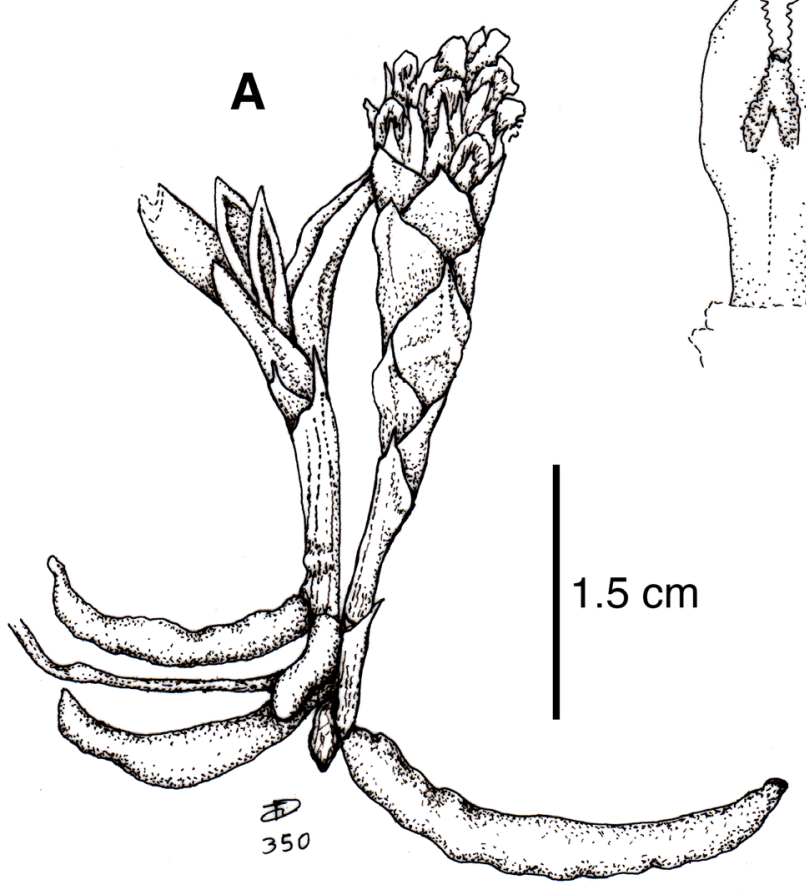

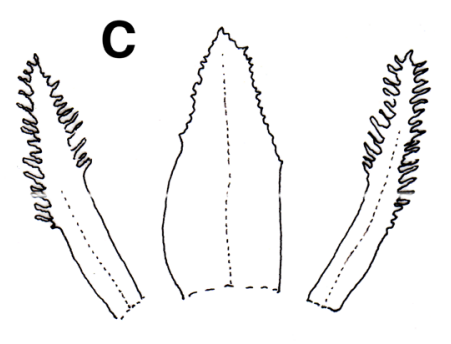
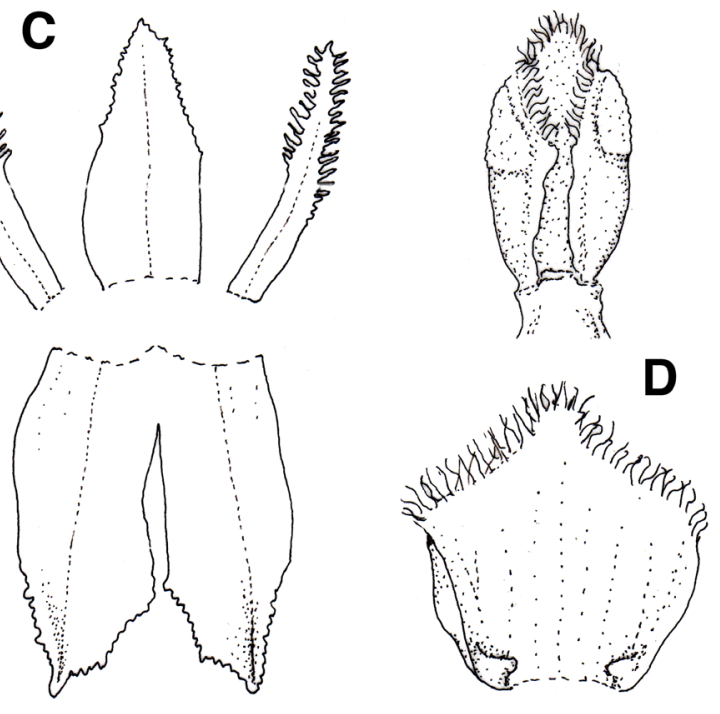

$5 \mathrm{~mm}$
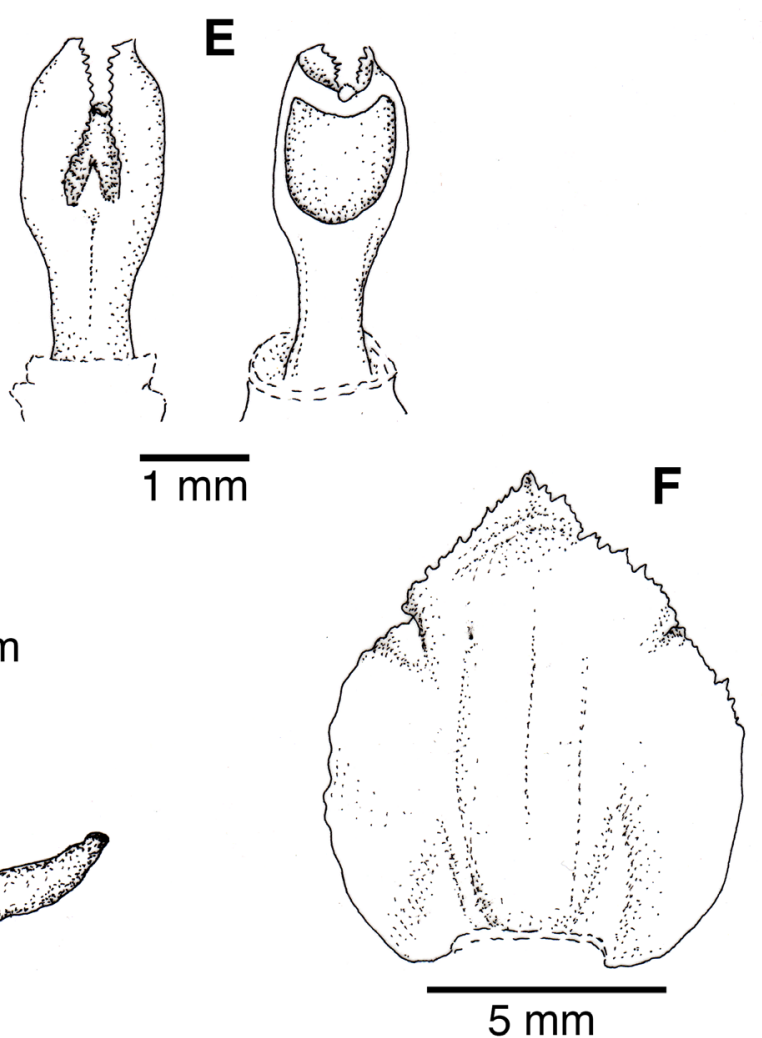

Figure 10. Myrosmodes nubigena. A. Habit. B. Flower, dorsal and ventral view. C. Dissected perianth. D. Lip, natural (up) and expanded out (down). D. Column, dorsal and ventral view. F. Floral bract. Drawing by D. Trujillo based on $A$. Cano E. et al. 21098. 
Distribution: Venezuela (Foldats 1969), Colombia, Ecuador, Peru and Bolivia (Vásquez et al. 2014). In Peru it has been recorded in the Departments of Cajamarca, Ancash, Lima and Cusco (Fig. 8), between 3700 and 4700 m elevation. In Ecuador it is known in the Provinces of Imbabura, Pichincha, Cotopaxi, Chimborazo and Napo (Garay 1978). In Colombia it is known in the Department of Meta (see below on notes about M. cleefii).

Habitat and ecology: Plants of this species grow in wetland and grasslands. Flowering plants have been recorded from May to August, and fruiting in September.

This species is distinguished by the 3-lobed lip, lacerate-fimbriate petals, the presence of clinandrium wings and the carinate sheaths that cover the scape of the inflorescence. These floral features were also showed in the illustration of the original publication (Reichenbach 1854 , see plate 8 , I, II, figs 1.10). The illustration of $M$. nubigena published in a recent work of Myrosmodes in Colombia in our opinion does not fully represent the features of the species (Szlachetko et al. 2014, see Figure 10): the lip has oblique thickenings, petals with ciliate margins at the apex and the sepals with entire margin at the apex. Although the plant and inflorescence agree with the species (in fact, these last drawings were taken from Reichenbach 1854).

Mytnik-Ejsmont et al. (2012) recently described Myrosmodes cleefii from Colombia. They proposed this tentative new species based on these features: "the lip is two times larger, widest in the middle, obtrullate in outline, lateral sepals cochleate with erose margins, dorsal sepal oblong-elliptic with keeled apex". Except for the apparently larger lip, this proposed taxon agrees with $M$. nubigena. We therefore refer this recently described taxon to the synonymy of M. nubigena.

There is a specimen of Jameson 816 at W (Rchb. Orch. $602)$, however this is not an isotype because it has a different date of preparation (November 1855).

Myrosmodes paludosa (Rchb.f.) P.Ortiz, Orquídeas Colombia ed. 2: 286. 1995.

Basionym: Altensteinia paludosa Rchb.f., Xenia Orchid. 3: 19. 1878.

TYPE. Bolivia. Prov. Larecaja, Viciniis Soratae; Gualata, Cabezas de Chilcani, [vancuiré] in paludosis. Reg. alpina, 3600-4400 m, October 1857- April 1858, G. Mandon 1169 (syntype: W! [Rchb. Orch. 620], (mixed, see notes). Bolivia. Prov. Larecaja, Viciniis Soratae, Gualata, apachetas de Lacatia de Chuchu in paludosis. Reg. alpina, 3700-4500 m, October 1857-April 1858, G. Mandon 1169 (syntype: W! [Rchb. Orch. 620], (mixed, see notes), isosyntypes: W-17504!, P-326295, K-364532, GH-1619, S-R218, NY8571).

Aa paludosa (Rchb.f.) Schltr., Repert. Spec. Nov. Regni Veg. 11: 150. 1912 (Fig. 11).

Synonym: Myrosmodes pumilio (Schltr.) C.A.Vargas, Lindleyana 10: 6. 1995. Aa pumilio Schltr., Repert. Spec. Nov. Regni Veg., Beih. 9: 52. 1921. TYPE: Peru. High Andes above Lima, 4500-4600 meters, Mar-Apr 1905, A. Weberbauer 5173 (holotype: B, destroyed).

Myrosmodes inaequalis (Rchb.f.) C.A.Vargas, Lankesteriana 11: 5. 2011. syn. nov. Aa inaequalis (Rchb.f.) Schltr., Repert. Spec. Nov. Regni Veg. 11: 150. 1912. Altensteinia inaequalis Rchb.f., Xenia Orchid. 3: 19. 1878. TYPE: Peru. Puno, Macusani in puna brava, June 1854, W. Lechler 1950 (holotype: W-23375!, isotype: W!, AMES38004, G-168908, G-168909, GOET-013941, K-364533, P-326290).

Plant small, 1.4-4.8 cm tall. Inflorescence 2.6-8.5 $\mathrm{cm}$ long (up to $10.0 \mathrm{~cm}$ long during fruit maturation), scape concealed by loosely, hyaline, imbricating sheaths with obtuse and brownish apex, spike cylindrical to cylindrical-conic, $1.0-2.6 \mathrm{~cm}$ long, 8 to 19 flowers (Fig. 1C, 5E). Floral bracts suborbicular, entire to undulate margin, hyaline, same size or little shorter than the flowers, brownish to blackish apex, 3.5-10.2 × 4.6-8.8 mm. Flowers small, sepals and petals white-hyaline with light green nerve, lip green with white at the margin, column green, anther brown. Dorsal sepal oblong to ovate-oblong, rounded to obtuse at the apex, revolute, $2.0-4.4 \times 1.0-1.9 \mathrm{~mm}$. Lateral sepals basally connate, broadly oblong, oblique, obtuse, apex entire or slightly erose, 2.6-5.5 $\times 1.0-2.2 \mathrm{~mm}$. Petals obliquely oblong to linearspatulate, obtuse to subacute, revolute, with the upper margin erose, $1.8-4.2 \times 0.5-1.2 \mathrm{~mm}$. Lip cucullate, apex revolute, suborbicular in outline when expanded, margin with moniliform hairs, two calli at the base, 2.0- 
$4.3 \times 2.3-4.3 \mathrm{~mm}$. Column short, dilated above, 1.5-2.2 $\times 1.0-1.7 \mathrm{~mm}$; rostellum truncate, shortly emarginate; stigma transverse, $0.5-0.9 \times 0.8-1.4 \mathrm{~mm}$. Anther 0.6-1.2 $\mathrm{mm}$ long. Ovary 3.0-5.6 mm long (Fig. 11.).

Specimens examined: Peru. Lima, Prov. Canta, Distrito Arahuay, Laguna Tambillo y alrededores, 41004500 m, pajonal dominado por Festuca sp. y bofedal dominado por Plantago tubulosa Decne, hierba escasa en el oconal, 24 May 2010, P. Gonzáles \& E. Navarro 1239 (USM-259483). Prov. Canta, Lachaqui, Quinan corral, $4100 \mathrm{~m}$, humedales en orilla de riachuelo, hierba terrestre de 5-8 $\mathrm{cm}$ de alto, hojas arrosetadas, flores blancas, 5 Jun 1993, G. Vilcapoma 2480 (USM278401). Prov. Canta, Lachaqui, en el camino de Quinan corral a Quinan laguna, 4200-4300 m, turbera de Distichia, hierba terrestre de 10-12 cm de alto; hojas arrosetadas, flores blancas, $29 \mathrm{Jul}$ 1993, G. Vilcapoma 2696 (USM-278400). Junín, Prov. Junín, Distrito Carhuamayo, alrededores del Área de Amortiguamiento de la RNJ, 4288 m, bofedal dominado por Distichia muscoides, sobrepastoreado, hierba escasa en bofedal, inflorescencia blanquecina, 7 Jun 2011, H. Beltrán 7117 (USM-246842). Prov. Huancayo, Distrito Acopalca, Cordillera Huaytapallana, 4521-4730, ladera rocosa, suelo franco a franco arenoso, pajonal y bofedales, en ladera rocosa con pajonal, hierba escasa con raíces carnosas, flores blancas, 5 May 2011, A. Cano et al. 20184 (USM). Huaytapallana, $4900 \mathrm{~m}, 10 \mathrm{~cm}$ hoch, Blüten gelb-braun, 2 Jun 1954, K. Rauh \& G. Hirsch 1732 (USM-165603, HEID- 0711534, not seen). [Yauli] Altamarca [Alpamarca], [1838-1842] Wilkes Expedition s.n. (W [Rchb. Orch. 622]!, GR-7355 photo seen). Huancavelica, Prov. Angares, Ccochaccasa, 4320-4330 m, ladera con suelo franco, pajonal bajo, 4 May 2014, A. Cano et al. 21912-b (USM). Puno, Prov. Carabaya, Distrito Corani, Chacaconiza, 4458 m, bofedal, hierba, escasa, flores blancas, 14 Mar 2014, P. Gonzáles 2997 (USM). Prov. Carabaya, Distrito Corani, Tantamaco, $4285 \mathrm{~m}$, pajonal, hierba de 5 cm. Flores blancas, 16 Mar 2014, P. Gonzáles 3022 (USM). Prov. Carabaya, Distrito Macusani, Pacaje Chacopata, 4897 m, vegetación de suelo crioturbado, hierba $5 \mathrm{~cm}$, escasa, flores blanco-verdosas, $17 \mathrm{Mar}$ 2014, P. Gonzáles 3057-a (USM).

Other Records: Peru. Lima, Prov. Yauyos, Distrito Miraflores, Uman, Apr 2015, A. Cano s.n. Prov.
Oyón, Distrito Oyón, zona adyacente a unidad minera Iscaycruz, $4580 \mathrm{~m}$, bofedal perturbado, dominado por Calamagrostis vicunarum (Wedd.) Pilg. y Werneria caespitosa Wedd., hierba escasa, en floración, 1 May 2014, W. Ramírez 1033. Prov. Oyón, distrito Oyón, zona adyacente a unidad minera Iscaycruz, $4580 \mathrm{~m}$, bofedal perturbado, dominado por Poa aequigluma Tovar y Werneria caespitosa, hierba escasa, en floración, 1 May 2014, W. Ramírez 1034. Apurimac, Prov. Cotabambas, Choquecca-Antuyo, $4319 \mathrm{~m}$, bofedal pequeño $(<1.0$ ha) estacional sobre planicie ligeramente inclinada con cuerpos de agua alrededor, vegetación dominada por Plantago rigida, Aciachne spp., Lachemilla pinnata (Ruiz \& Pav.) Rothm., hierba, escasa, suele crecer entre las rosetas de Plantago tubulosa, 29 Mar 2015, W. Ramírez 1036. Cusco: Cerro de Colquipata, 3900-4000 $\mathrm{m}$, on open grassy puna, perennial herb, flowers white, 1 May 1925, F. Pennell 13747 (AMES-58421, photo seen). Puno: Prov. Carabaya, Fauchinta, Allinccapac, $4600 \mathrm{~m}$, césped húmedo, corola blanca laciniate, 1 Apr 1948, C. Vargas 7160 (AMES-65008, photo seen). Prov. Melgar, Hda Hanuvamani(?), 4400 m, bofedales, hierba, Mar 1970 C. Antegana 68 (CUZ-23624, photo seen).

Distribution: Peru and Bolivia. In Peru it has been recorded in the Departments of Lima, Junín, Huancavelica, Apurimac, Cusco and Puno (Fig. 8), between 4100 and $4900 \mathrm{~m}$ elevation. In Bolivia it is known in the Department of La Paz, Cochabamba, Potosi and Tarija (Vásquez et al. 2014).

Habitat and ecology: Plants of this species grow in wetland dominated by Distichia muscoides, Plantago tubulosa, Calamagrostis vicunarum, Poa aequigluma and Werneria caespitosa, grasslands and in cryoturbated soils. Flowering plants have been recorded from March to June.

In the protologue of Altensteinia paludosa, Reichenbach (1854) cited two specimens of G. Mandon 1169 mounted in different sheets (he wrote "Allia scheda") with different collection data: "... Gualata, Cabezas de Chilcani, [vancuiré] in paludosis. Reg. alpina, 3600-4400 m" and "... Gualata, apachetas de Lacatia de Chuchu in paludosis. Reg. alpina, 3700-4500 m". They represent syntypes (McNeill et al. 2012, ICN Art. 9.5). In Reichenbach's herbarium housed at $\mathrm{W}$, it was found one single sheet composed of several dry plants, a drawing, handwritten notes of 

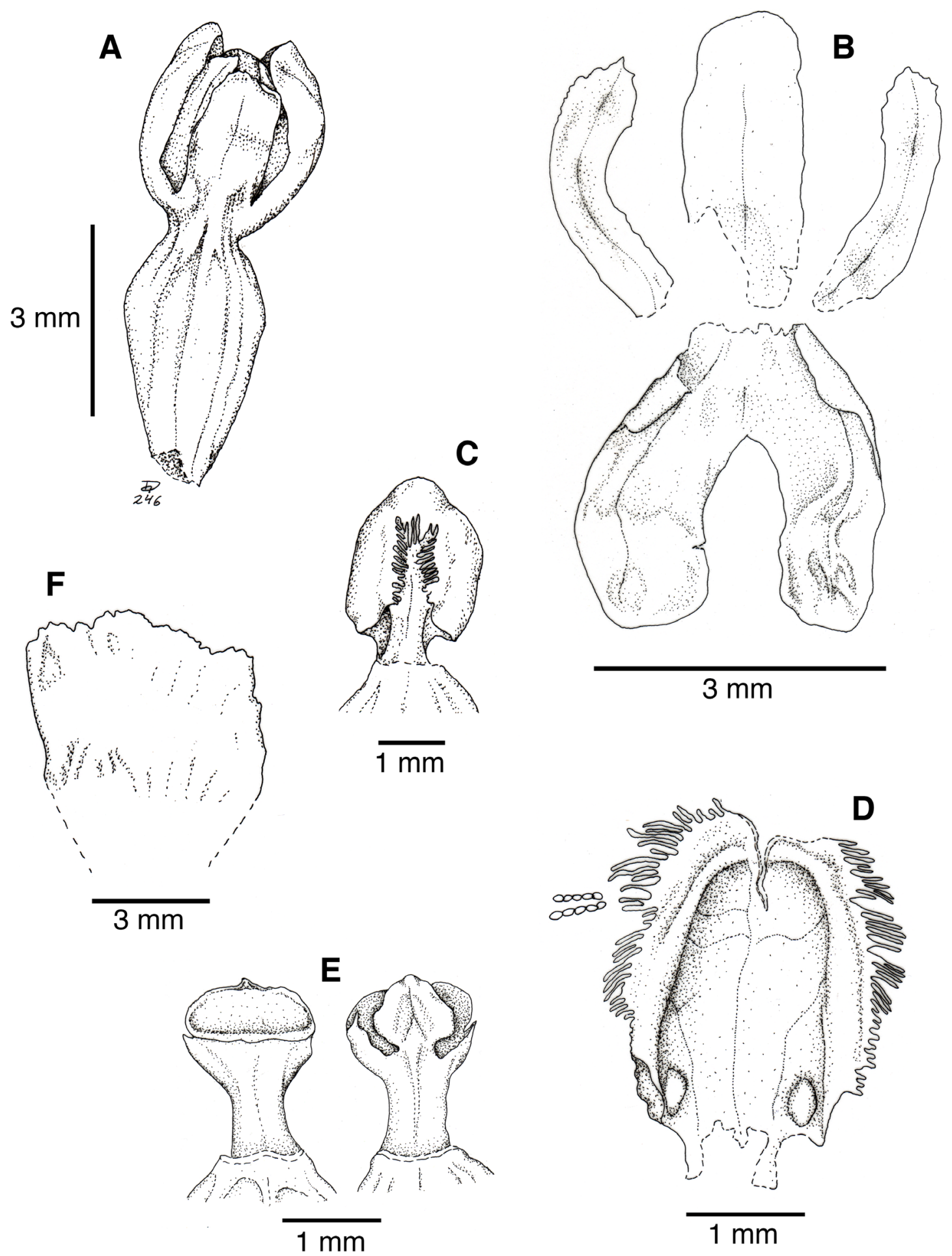

FiguRE 11. Myrosmodes paludosa. A Flower. B. Dissected perianth. C. Column and lip. D. Lip. E. Column, dorsal and ventral view. F. Floral bract. Drawing by D. Trujillo based on G. Mandon 1169 (W). 
Reichenbach and two labels of G. Mandon 1169. The labels have different collection data which matches with each of the syntypes. Therefore, presumably, at some point after the species description, the material of both syntypes were mixed and mounted on a single sheet. An additional specimen of G. Mandon 1169 was found at W (no.17504); however, it was not part of the Reichenbach collection (this was originally at the Herbarium of the Musei Caesarei Vindobonenesis). Several specimens of G. Mandon 1169 were located in different herbaria: BR, G, GH, GOET, K, MPU, NY, $\mathrm{P}$ and $\mathrm{S}$. Nonetheless, the collection data are not the same in all the specimens and only a few fully agree with one of the syntypes.

The specimens of G. Mandon 1169, with the following herbarium acronym and accession number have collection data that do not fully agree with the syntypes: BR-997331 (photo seen, mixed with an Aa specimen), G-168828 (photo seen), GOET-8362 (photo seen), MPU-17164 (photo seen), NY-8572 (photo seen), P-326294 (photo seen) and P-326296 (photo seen).

Schweinfurth (1958) in his work Orchids of Peru placed to Aa [Myrosmodes] brevis and $A a$ [Myrosmodes] pumilio as synonyms of Altensteinia [Myrosmodes] paludosa. Here, we consider to $M$. brevis as a distinct species (see notes of $M$. brevis) but agree in considering M. pumilio as a synonym. Vargas (1995) placed M. pumilio in subgenus Rhynchocarpaea (Schltr.) C. Vargas. Members of this subgenus are recognized by displaying a rostrate ovary and a clawed lip with a cordate base; however, we do not find those features in the original description or illustration (Mansfeld 1929, plate 105, nr. 412) of the species. Hence, M. pumilio belong to subgenus Myrosmodes.

After examination of the type material of $M$. inaequalis at W (see illustration in Trujillo \& Vargas 2012), we did not find morphological differences with M. paludosa. Therefore, it is here proposed as a synonym of the $M$. paludosa.

Based on the Peruvian specimens studied here, there is no record of M. paludosa for Northern Peru; (apparently Lima is the northern limit). The species has not been recorded yet in Ecuador. Foldats (1969) and Szlachetko et al. (2012) reported this species for Venezuela and Colombia, respectively. However, the illustration shown in the work of Foldats (fig. 152, page 408) and one (of the four) specimen cited there (J. Steyermark 55667, AMES-64406, photo seen) do not represent M. paludosa (it is M. cf. rostrata). Therefore, it is uncertain if this species really occurs in Venezuela. A careful examination of the Colombian and Venezuelan specimens, determined as M. paludosa, are necessary in order to confirm if this species really occurs in those countries.

Hauman (1920) recorded Aa [Myrosmodes] paludosa for Argentina based on the examination of two specimens: Hauman s.n. (Prov. of Jujuy) and Jörgensen 1598, LIL, [AMES-49216, photo seen] (Prov. of Catamarca). However, the floral features described in that work do not agree with M. paludosa: petals narrowly linear, lateral sepals carinate, lip obscurely 3-lobed with a short midlobe and floral segments from 6.0 to $8.0 \mathrm{~mm}$ long. These features agree with $M$. gymnandra. Hence, it seems that the Myrosmodes species that occurs in Argentina is $M$. gymnandra but not M. paludosa.

Myrosmodes rhynchocarpa (Schltr.) Garay, Fl. Ecuador 9: 171. 1978.

Basionym: Aa rhynchocarpa Schltr., Repert. Spec. Nov. Regni Veg. Beih. 8: 38. 1921. Altensteinia rhynchocarpa (Schltr.) A.D. Hawkes, Phytologia 3: 248. 1950.

TYPE: Ecuador. Pichincha, in "paramo" in monte Antisane, L. Sodiro 178 (holotype: B destroyed, isotypes: QPLS, not seen, $\mathrm{S}$, not seen).

Synonym: Myrosmodes cochlearis Garay, Fl. Ecuador 9: 169. 1978. syn. nov. TYPE: Ecuador. Prov. Carchi, Paramos 12 miles [km in error] W of Tulcán, [3300 m, 10 Aug 1923], A.S. Hitchcock 20927 (holotype: AMES-71554, photo seen; isotype: US, photo seen, NY, photo seen).

Plant small, 1.2-3.5 cm tall. Inflorescence 2.5-8.0 $\mathrm{cm}$ long (up to $12.0 \mathrm{~cm}$ long during fruit maturation), scape concealed by loosely, hyaline, imbricate sheaths with obtuse apex, spike conic (cylindric-conic during fruit maturation), $1.5-3.5[4.0] \mathrm{cm}$ long, $1.3-2.5 \mathrm{~cm}$ diameter, 13 to 55 flowers (Fig. 1A, 5C). Floral bracts ovate-elliptic, obtuse, hyaline, somewhat shorter than the flower, 7.2-16.0 × 2.5-9.8 mm (Fig. 1D, F,). Flowers small, sepals and petals white-hyaline, lip green with white at the margin, column green, anther brown (Fig. 12). Dorsal sepal oblong to ovate, 
obtuse, revolute, $2.0-4.3 \times 1.1-2.2 \mathrm{~mm}$. Lateral sepals basally connate (up one-quarter their length), oblong to ovate-oblong, obtuse, concave, 2.8-4.4 × 1.1-2.6 $\mathrm{mm}$. Petals more or less obliquely oblong, obtuse, revolute, the upper margin entire to slightly irregular, 2.0-4.4 × 0.8-1.2 mm. Lip cucullate, apex revolute, shortly clawed, base cordate, suborbicular to ovate or obscurely 3-lobed in outline when expanded, margin with dense moniliform hairs, two oblong calli at the base (slightly oblique and oriented towards the center), 3.0-5.0 $\times 2.8-5.5 \mathrm{~mm}$. Column short, dilated above, $1.5-3.0 \times 1.0-1.8 \mathrm{~mm}$; rostellum truncate, emarginate; stigma transverse, $0.4-1.0 \times 0.6-1.2 \mathrm{~mm}$. Anther $0.7-$ $1.5 \mathrm{~mm}$ long. Ovary ellipsoid to oblong, long-rostrate at apex, 4.4-24 × 0.8-4.0 mm (Fig. 12, 13).

Specimens examined: Peru. La Libertad, Prov. Santiago de Chuco, Distrito Quiruvilca, bofedales de Quesquenda, al costado de la carretera CayacullanHuamachuco, 4100 m, 27 May 2005, D. Trujillo 219 (SEL-in spirit). Ancash, Prov. Pallasca, Distrito Conchucos, Abra entre Quebrada Magistral y Colparacra, 4480-4490 m, ladera con suelo franco, pajonal alto, 23 May 2012, A. Cano et al. 21153 (USM). Prov. Huaraz, Huascaran National Park, Quebrada Rajucolta, 4000-4150 m, brushfields on moderate S-facing slopes, soil of granitic morainal material, bouldery, terrestrial, foliage and inflorescence arising from deeply buried, fleshy roots, flowers white, pastures, 17-18 Apr 1986, D. Smith et al. 12186 (USM-102718). Prov. Huaraz, Distrito Independencia, quebrada Quilcayhuanca, $3842 \mathrm{~m}$, planicie con pendiente de $5-10^{\circ}$, suelo franco, pajonal bajo, hierba con raíces carnosas, frecuente, flores blancas, 1 Jul 2012, A. Cano et al. 21281 (USM). Prov. Huaraz, Huascaran National Park, Quebrada Shallap, $3900 \mathrm{~m}$, overgrazed bottom, grassland with some shrubs, herb from fleshy root, leaves appearing like rosette, inflorescence arising from roots, flowers white, 20 Feb 1985, D. Smith et al. 9675 (USM-67926). Prov. Carhuaz, Huascaran National Park, Quebrada Ishinca, valley bottoms, 4100-4250 m, grassland/shrubland, soils alluvial, moraine or organic in boggy spots, leaves arising from fleshy roots, at soil level appear to be rosette, flowers white infl. from roots, $14 \mathrm{Feb} 1985$, "Chinankak-koriwakak", D. Smith et al. 9549 (USM67595). Prov. Huaylas, Huascaran National Park, Quebrada Alpamayo at foot of snow free peak above

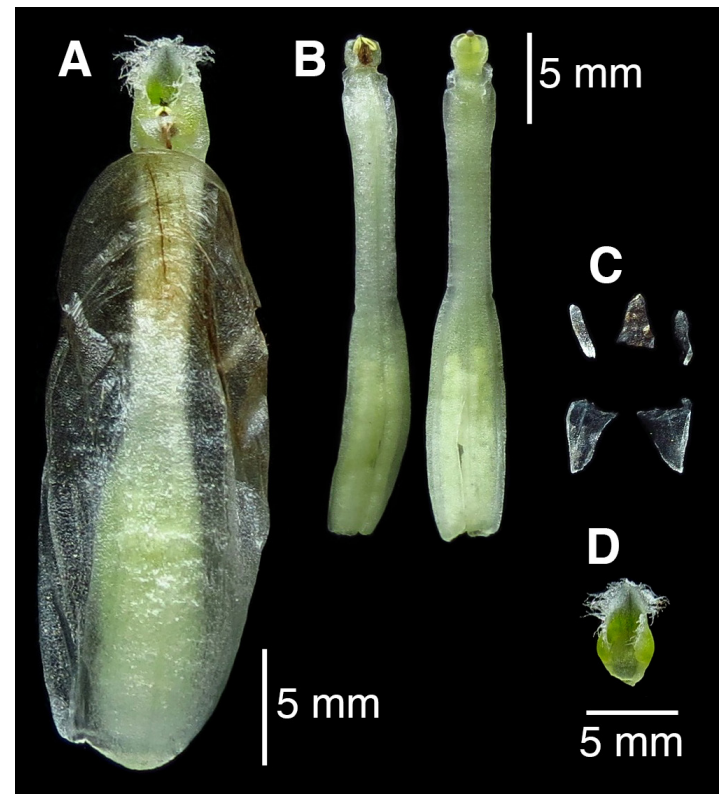

FIGURE 12. Myrosmodes rhynchocarpa. A Flower. B. Column and ovary dorsal and ventral view. C. Dissected perianth. D. Lip. Photograph by D. Trujillo based on $A$. Cano 21592.

lago Jancarurish, 4350-4500 m (also seen at $4700 \mathrm{~m}$ ), grassy slopes and bottoms on morainal material, parts appear to be frequently burned, terrestrial, all parts arise from fleshy roots; flowers whitish green, faint foetid odor, 9 Mar 1985, D. Smith et al. 9768 (USM-69655). Prov. Huari, Huascaran National Park, Quebrada Pucaraju (Pucaragra, fide map), a lateral valley of Quebrada Rurichinchay, 3900-4200 m, grassland with brushfields, bogs, and Polylepis weberbaueri woods; bottoms and gentles slopes; soils of morainal material, terrestrial from fleshy roots, flowers greenish white, 15 Jun 1986, D. Smith et al. 12691 (USM-104891). Prov. Huari, Huantar, Quebrada Carhuascancha, 4160 m, ladera rocosa, suelo franco, bosque de Polylepis y pajonal bajo, hierba terrestre, escasa, flores blancas, 1 Jul 2012, A. Cano et al. 21355 (USM). Prov. Huari, Huascaran National Park, Quebrada Rima Rima, a lateral valley of Quebrada Carhuascancha, 4200-4440 $\mathrm{m}$, grassland; $\mathrm{N}$ to NW facing, steep slopes, granitic outcrops and morainal material, on dry ridge, herb from fleshy roots, fruits brown, 7 May 1986, D. Smith et al. 12306 (USM-152807). Prov. Yungay, Quebrada Llanganuco, 3890-4063 m, ladera con suelo francoarenoso con grandes rocas, parches de Bosques de 

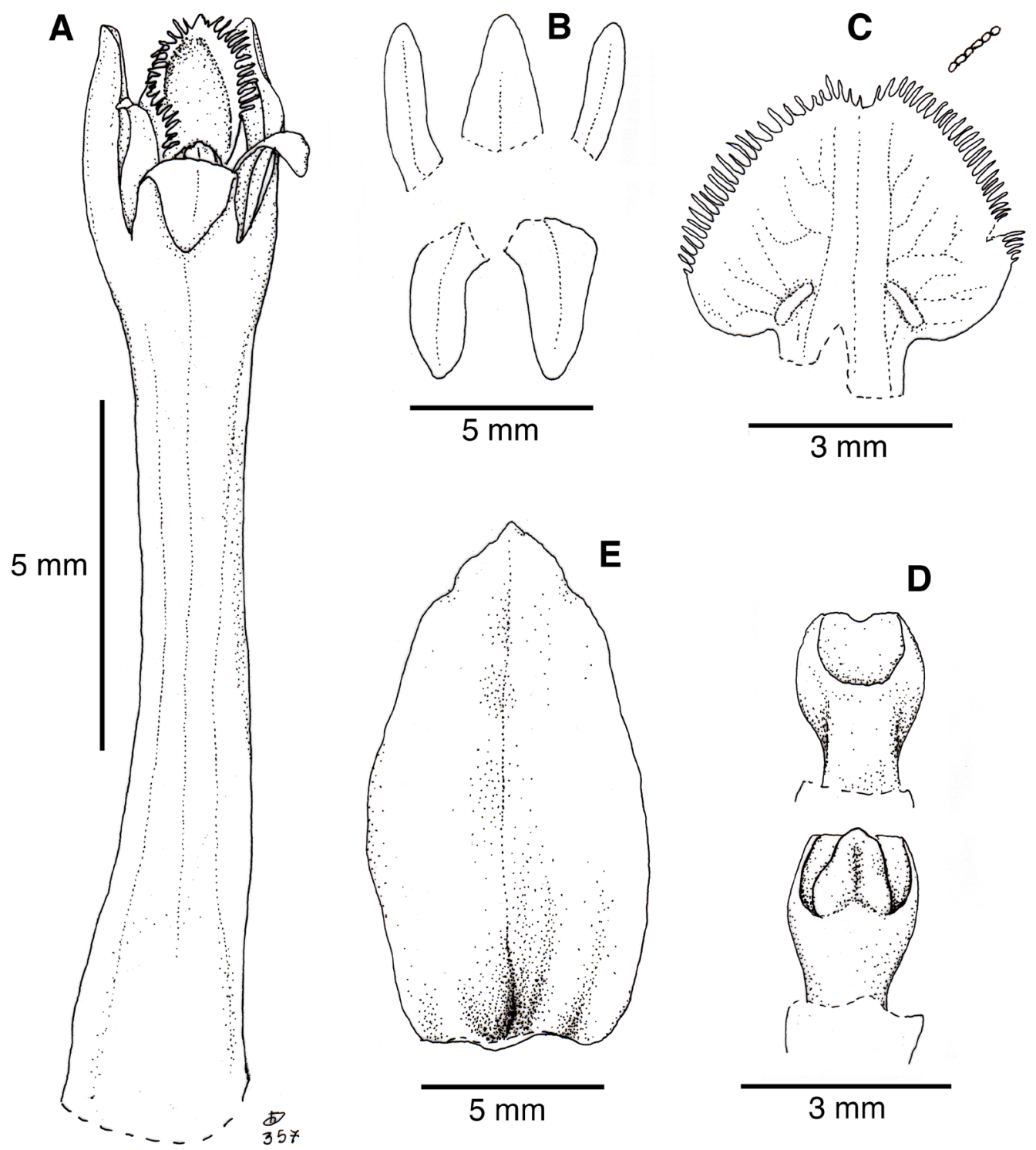

Figure 13. Myrosmodes rhynchocarpa. A Flower. B. Dissected perianth. C. Lip. D. Column ventral and dorsal view. E.

Floral bract. Drawing by D. Trujillo based on A. Cano 21355.

Polylepis (ladera izquierda) y matorral con abundancia de Festuca, hierba, con raíces carnosas, escasa, flores blancas, 11 Jul 2013, A. Cano \& P. Polk 21592 (USM) Prov. Bolognesi, Punta de "Tecca" entre Chiquian y Conococha, $4200 \mathrm{~m}$, puna, crece protegida por otras hierbas, planta suculenta, raíces fasciculadas y tuberosas, 5 May 1952, E. Cerrate 1531 (USM263062). Prov. Bolognesi, $4100 \mathrm{~m}$, Tinya, Valle del Fortaleza, pradera con arbusto, 30 Apr 1956, E. Cerrate 2693 (USM-263114). Junín, Prov. Junín,
Ondores, 4300 m, Pampa pedregosa, 13 Sep 1976, U. Pettersson 153 [in part] (USM-167406).

Other ReCords: Peru. Apurímac, Prov. Cotabambas. Distrito Chalhuahuayo, Cuchuhuacho, 4143 m, hierba terrestre, que se desarrolla en el bofedal, flores secas, rizoma con bulbos blancos de $3-5 \mathrm{~cm}$, tallo de $5-10 \mathrm{~cm}$, 27 Aug 2015, E. Briceño 2026.

Distribution: Colombia (Szlachetko et al. 2012), Ecuador and Peru. In Peru it has been recorded in 
the Departments of La Libertad, Ancash, Junín, and Apurimac (Fig. 4), between 3850 and 4500 m elevation. In Ecuador it is known in the Provinces of Carchi (as Myrosmodes cochlearis, see below), Pichincha and Cotopaxi (Garay 1978).

Habitat And ecology: Plants of this species grow in wetland, grasslands, hillsides with some shrubs or in patches with Polylepis trees. Flowering plants have been recorded from February to July, and fruiting between May to September.

Dunsterville \& Garay (1966) recorded and illustrated (see page 27) a specimen from Venezuela as Altensteinia [Myrosmodes] rostrata; although they pointed out the locality where the plants were recorded, they did not cite a voucher. This Venezuelan specimen differs from the type of M. rostrata by having a spadelike rostellum (as was, cited) and short anther instead of having a 3-lobed rostellum and the anther exceeding the apex of the stigma.

In 1978, Garay described Myrosmodes cochlearis as a new species for Ecuador and Venezuela. In this publication, Garay used the same illustration of Dunsterville \& Garay (1966), instead of a drawing based on the holotype: A.S. Hitchcock 20927 (AMES). In the protologue, Garay cited two additional specimens from Ecuador but not from Venezuela, he only indicated "Also Venezuela". Drawings of dissected flowers of A.S. Hitchcock 20927 are housed at AMES and K (here, a copy a Garay's drawing). After the revision of the drawings (of A.S. Hitchcock 20927) and the original description of $M$. cochlearis, we did not find distinctive features that distinguish it from $M$. rhynchocarpa. We therefore refer M. cochlearis to the synonymy of $M$ rhynchocarpa.

ACKNOWLEDGEMENTS. We thank the staff and curators of AMES, MOL, USM, and $\mathrm{W}$ for allowing access to their collections; to Dámaso W. Ramírez, Edith Briceño and Diego Rodríguez for providing critical information. Asunción Cano thanks to Kenneth R. Young by their financial support for several field trips to Ancash department.

\section{LiteRATURE CITED}

Álvarez-Molina, A. \& Cameron, K. M. (2009). Molecular phylogenetics of Prescottiinae s.l. and their close allies (Orchidaceae, Cranichideae) inferred from plastid and nuclear ribosomal DNA sequences. American Journal of Botany, 96(5), 1020-1040. DOI: 10.3732/ajb.0800219

Garay, L. A. (1978). Orchidaceae. Cypripedioideae Orchidoideae Neottioideae. In: G. Harling \& B. Sparre (Eds.), Flora of Ecuador, 225(1). University of Goteborg, Stockholm, Sweden.

Dunsterville, G. C. K. \& Garay, L. A. (1966). Venezuelan Orchids Illustrated V. Andre Deutsch Limited, London, UK.

Foldats, E. (1969). Orchidaceae. In T. Lasser (Ed), Flora de Venezuela Tomo XV. Parte I (pp. 1-502). Editorial Instituto Botánico. Caracas, Venezuela.

Hauman, L. (1920). Les orchidées argentines (deuxiéme serie). Anales de la Sociedad Cientifica Argentina, 90, 95-154.

McNeill, J. et al. (eds.). (2012). International Code of Botanical Nomenclature (Melbourne code), adopted by 18th IBC, Melbourne, 2011. Regnum Vegetabile 154.

Mansfeld, R. (ed.). (1929). Figuren-Atlas zu den Orchideenfloren der südamerikanischen Kordillerenstaaten. Repertorium Specierum Novarum Regni Vegetabilis, Beihefte 57.

Mytnik-Ejsmont, J., Szlachetko, D. L. \& Nowak, S. (2012). Three new species of Myrosmodes (Orchidaceae, Spiranthoideae) from Colombia and Ecuador. Plant Systematics and Evolution, 298, 1909-1916. DOI: 10.1007/s00606-012-0690-9

Novoa, P., Vargas C. \& Cisternas. M. A. (2015). Myrosmodes nervosa (Orchidaceae, Cranichidinae, subgenus Myrosmodes): a new combination of Myrosmodes to Chile. Gayana Botanica, 72(1), 152-154. DOI: 10.4067/ S0717-66432015000100019

Ortiz, P. (1995). Orquídeas de Colombia. Corporación Capitalina de Orquideología, Bogota. 2da. Ed.

Reichenbach, H. G. (1854). Altensteinia, Aa and Myrosmodes. Xenia Orchidacea, 1, 17-19.

Reichenbach, H. G. (1878). Orchideae Mandonianae. Xenia Orchidacea, 3, 17-19.

Schlechter, R. (1912). Die Orchideen Gattungen Altensteinia HBK, Aa Rchb.f. und Myrosmodes Rchb.f.. Repertorium Specierum Novarum Regni Vegetabilis, 1, 147-150.

Schlechter, R. (1920a). Orchidaceae novae et criticae. Repertorium Specierum Novarum Regni Vegetabilis, 16, 353-358.

Schlechter, R. (1920b). Orchidaceae novae et criticae. Repertorium Specierum Novarum Regni Vegetabilis, 16, 437-450.

Schlechter, R. (1921). Die Orchideenfloren der südamerikanischen Kordillerenstaaten IV. Peru. Repertorium Specierum Novarum Regni Vegetabilis, Beihefte, $9,1-182$.

Schlechter, R. (1922). Die Orchideenfloren der 
südamerikanischen Kordillerenstaaten V. Bolivia. Repertorium Specierum Novarum Regni Vegetabilis, Beihefte, 10, 1-80

Schweinfurth, C. (1958). Orchids of Peru. Fieldiana, Botany, 30(1), 1-260.

Szlachetko, D. L., Mytnik-Ejsmont, S., Nowak, S. \& Kolanowska, M. (2014). Revision of the Genus Myrosmodes (Orchidaceae, Spiranthoideae) in Colombia. Systematic Botany, 39(3), 740-749. DOI: 10.1600/036364414X681491

Trujillo, D. \& Vargas, C. (2011). New species of $A a$ and new combinations in Myrosmodes (Orchidaceae: Cranichidinae) from Bolivia and Peru. Lankesteriana, 11(1), 1-8.
Vargas, C. (1995). New combinations in Myrosmodes Rchb.f. (Orchidaceae) Lindleyana, 10, 5-6.

Vásquez, R., Ibisch, P. L. \& Gerkmann, B. (2003). Diversity of Bolivian Orchidaceae-A challenge for taxonomic, floristic and conservation research. Organisms Diversity \& Evolution, 3, 93-102 (electronic supplement 4).

Vásquez, R., Ibisch, P. L. \& Jiménez-Pérez, I. (2014). Orchidaceae. En: P. M. Jørgensen, M. H. Nee \& S. G. Beck (Eds.), Catálogo de las Plantas Vasculares de Bolivia (pp. 894-989). Monographs in Systematic Botany from the Missouri Botanical Garden 127(1-2).

Williams, L. O. (1939). Las Orquidáceas del noroeste argentino. Lilloa, 4(2), 337-375. 
